\title{
Lobbying Expenditures on Migration: A Descriptive Analysis ${ }^{1}$
}

\author{
Giovanni Facchini ${ }^{2}$ \\ Anna Maria Mayda ${ }^{3}$ \\ Prachi Mishra ${ }^{4}$ \\ University of Nottingham and \\ CEPR \\ Georgetown University and \\ International Monetary Fund \\ CEPR
}

\begin{abstract}
In this paper we carry out a descriptive analysis of lobbying expenditures on migration in the US between 1998 and 2005. While PAC contributions and lobbying are in general positively correlated, our results suggest that this is not the case when it comes to lobbying on migration. As a result, any analysis of the role of lobbying in migration should not focus on PAC contributions alone. Comparing lobbying on migration and trade, we find that substantially more resources are spent on the latter than on the former. Finally, lobbying on migration appears to be more concentrated than lobbying on trade both across sectors and across organizations.
\end{abstract}

\footnotetext{
${ }^{1}$ We thank for useful comments seminar participants at the CESifo workshop on "Migration Policies" in Munich. The views expressed in this paper are those of the authors and do not necessarily represent those of the IMF or IMF policy.

${ }^{2}$ School of Economics, University of Nottingham, University Park, Nottingham, NG7 2RD, United Kingdom. Email: Giovanni.Facchini@nottingham.ac.uk.

${ }^{3}$ Corresponding author. Department of Economics and School of Foreign Service, Georgetown University, Washington, DC, 20057, USA. Email: amm223@georgetown.edu.

${ }^{4}$ International Monetary Fund, Washington DC, 20431, USA. Email: pmishra@imf.org.
} 


\section{Introduction}

Only a small minority of voters in the main destinations of immigrant flows favours more open migration policies. Based on the National Identity Module of the International Social Survey Programme (ISSP), in 1995, less than 10 percent of the respondents was in favour of increasing the number of immigrants to their country. ${ }^{5}$ The fraction of voters in favour of further immigration was also very low in 2003 (Mayda 2006). According to the ISSP survey carried out in that year, ${ }^{6}$ only 11 percent of respondents was in favour of increasing the number of foreigners allowed into the country (Facchini and Mayda 2008). ${ }^{7}$ More recently, a survey carried out by the German Marshall Fund revealed that, in 2011, in five European countries ${ }^{8}$ only 4 percent of the population felt that there were too few immigrants - i.e., only 4 percent of the population was presumably in favour of a more open policy stance - while 47 percent felt that there were too many of them. ${ }^{9}$

Given the extent of opposition to immigration revealed by public opinion surveys, one might wonder why governments allow migration to take place at all. In fact a simple median-voter model, ${ }^{10}$ applied to the voters' preferences we observe in the data, would predict close-to-zero flows, while actual arrivals are non trivial in number. How can this "public opinion puzzle" - as has been labeled in the political science literature (Freeman 1992, Joppke 1998) - be explained? Why are policy-makers willing to let the size of migration be much larger than desired by the majority of their voters? One very likely explanation of the discrepancy between voters' opinions and the actual size of migration flows is that the political process through which heterogeneous voters' preferences are aggregated is richer than a simple referendum (where each voter has the same weight). In particular domestic interest groups, many of which are pro-migration, are likely to play an important role. ${ }^{11}$ In fact, there is abundant anecdotal evidence supporting this view

\footnotetext{
${ }^{5}$ The 1995 ISSP survey covered more than 20 high- and middle-income countries.

${ }^{6}$ The 2003 ISSP survey covered 33 high- and middle-income countries.

${ }^{7}$ In particular, in the United States, the fraction of voters in favor of increasing the number of immigrants to the US was $8 \%$ in 1995 and $10 \%$ in 2003.

${ }^{8}$ France, Germany, Italy, Spain and United Kingdom.

${ }^{9}$ The corresponding percentages in the United States were in the same year $4 \%$ and $44 \%$.

${ }^{10}$ In the median voter model, policies are chosen according to the preferences of the majority (for example, in a referendum).

${ }^{11}$ Note that, in standard labor-economics models, immigration produces net gains in the destination country as gains to the capital owners from cheap labor outweigh losses to the workers (see, for example, Borjas
} 
dating back to the great migration of the nineteenth century as well as to more recent developments. In the past, active subsidization of immigration has been demanded and obtained by business associations in many labor-scarce countries, as documented by Timmer and Williamson (1996). In her study of the political economy of the introduction of the 1917 Literacy Test provision in the U.S., Goldin (1994) points out that capital owners were against this restrictive measure and actively lobbied against it.

More recently, business lobbies have been in favor of migration both in the U.S. and in Europe. For instance, during the "dot com" boom at the end of the nineties, high tech firms have intensively and successfully lobbied the U.S. Congress to increase the number of H-1B visas. ${ }^{12}$ At the same time, U.S. hospitals and healthcare providers have been able to secure an increase in the number of $\mathrm{H}-1 \mathrm{C}$ visas awarded to foreign nurses. Finally, after the 2006 U.S. midterm elections, the vice-president of Technet, a lobbying group for technology companies, stressed that the main goal of the reforms proposed by her group was the relaxation of migration policy constraints. ${ }^{13} \mathrm{New}$ visa categories have also been introduced in the U.S. as the result of lobbying activities. An interesting example is the case of $\mathrm{H}-2 \mathrm{R}$ visas. In 2005, the quota for $\mathrm{H}-2 \mathrm{~B}$ visas was filled with none of them going to the seafood industry in Maryland. ${ }^{14}$ This industry started heavy lobbying of the Maryland senator Barbara A. Mikulski, who was able to add a last-minute amendment to the Tsunami Relief Act (P.L. 109-13) of May 11, 2005 (Cox News May 4, 2006). As a result, a new visa category was introduced, H-2R visas. The requirements for $\mathrm{H}-2 \mathrm{R}$ visas are the same as for $\mathrm{H}-2 \mathrm{~B}$ visas, but there is no quota. As long as the individual has held an $\mathrm{H}-2 \mathrm{~B}$ visa in one of the previous three fiscal years, he can get an

1995). Therefore, another explanation of the public opinion puzzle is that, besides political considerations, policymakers also care about social welfare.

${ }^{12}$ The H-1B is a non-immigrant visa that enables U.S. employers to temporarily hire foreign workers in specialty occupations, which typically require the attainment of a bachelor's degree as a minimum. The work permit lasts for three years, is tied to the initial sponsor, and the current cap is set at 85,000 per year. Writing at the peak of the boom Goldsborough (2000) pointed out: "Immigration policy today is driven by businesses that need more workers, skilled and unskilled, legal and illegal [...] During the annual debate on $\mathrm{H}-1 \mathrm{~B}$ visas two years ago, Silicon Valley executives trooped before Congress, warning of a Y2K computer disaster unless the number of H-1B visas was increased."

${ }_{13}^{13}$ CIO, December 19 2006, available at http://www.cio.com/article/27581/

${ }^{14} \mathrm{H}-2 \mathrm{~B}$ visas are for temporary workers in unskilled, seasonal, non-agricultural occupations (for example, in the planting-pine-trees industry; the resort industry, the seafood industry, the gardening industry in the North of the United States, etc.). 
$\mathrm{H}-2 \mathrm{R}$ visa. This has substantially expanded the number of temporary, non-agricultural workers allowed to enter the U.S..

In Europe, pro-migration business interest groups appear to play a similar role. For example, in the UK, associations like the Business for New Europe group (BNE) $)^{15}$ have issued statements suggesting that "...the UK should continue with its open door policy", on the eve of the discussion on introducing a cap on migration from Bulgaria and Romania, once the two countries became members of the European Union (Agence France Press, August 30 2006).

Note that not all interest groups are in favor of migration. Labor unions, for example, have historically been an important political force against free migration. However, the evidence in the literature is that anti-migration pressures by interest groups have become less effective over time. ${ }^{16}$

While anecdotal evidence on the role played by interest groups is abundant, systematic empirical analyses are scarce. The only studies in the literature, which empirically investigate the political economy of migration policy, with a specific focus on lobbying activity, are Hanson and Spilimbergo (2001), Facchini and Mayda (2008), Facchini, Mayda and Mishra (2011) and Kerr, Lincoln and Mishra (2013) (details of each paper are described in Section 2.). In particular, Facchini, Mayda and Mishra (2011) analyze the impact of lobbying activity on migration policy in the U.S. using a newly available dataset on lobbying expenditures on immigration. While the dataset provides information at the firm level, Facchini, Mayda and Mishra only focus on variation across sectors (since data on the number of visas - which they use as the dependent variable and on other relevant economic variables are only available at that level).

In this paper, we use the same dataset as Facchini, Mayda and Mishra (2011) and carry out a descriptive analysis of lobbying expenditures on migration, in the United States, both across sectors and across lobbying organizations, between 1998 and $2005 .{ }^{17}$

\footnotetext{
${ }^{15}$ This is a UK based pressure group. The heads of the supermarket chain Sainsburys and the head of the European division of the investment bank Merrill Lynch were among the signatories.

${ }^{16}$ See, for example, Facchini and Mayda (2008). This paper's results are consistent with the fact that, in recent years, U.S. labor unions have substantially toned down the rhetoric against migration.

${ }^{17}$ The political environment has changed significantly since 2005 . For example, the groups applying for $\mathrm{H}-$ $1 \mathrm{~B}$ visas have changed significantly since the early 2000 s, with a shift towards Indian firms. Consider for example the Citizens United decision in 2010 which allowed corporations and unions to spend unlimited sums on ads and other political tools to convince people to vote for/against a candidate.
} 
The dataset, developed by the Center for Responsive Politics (CRP), contains information on the policy area targeted by lobbying activities. As a result, we can quantify the lobbying expenditures that are channeled towards shaping immigration policy. This represents a significant improvement in the quality of the data relative to the previous literature which has used, instead, political action committees (PAC) campaign contributions. ${ }^{18}$ First, PAC contributions represent only a small fraction $(10 \%)$ of targeted political activity, the remainder being made up by lobbying expenditures. Second, PAC contributions cannot be disaggregated by issue and, thus, cannot be easily linked to a particular policy. Finally, we compare our findings on lobbying on migration to results on lobbying on trade.

Several interesting points emerge from our analysis. First, while PAC contributions and lobbying are in general positively correlated, our results suggest that this is not the case when it comes to lobbying on migration. As a result any analysis that focuses on the role of pressure group activity in affecting migration should take advantage of these new data on lobbying, rather than relying only on PAC contribution data. Second, while overall lobbying expenditures increased steadily over our sample period, lobbying on both migration and trade appears to fluctuate more. Third, the total amount spent on lobbying for immigration and trade never exceeded 6 percent of the total lobbying contributions, and the total amount contributed with the purpose of shaping trade policy was typically four to six times larger than the amount contributed to shape migration policy (see Table 1). Fourth, turning to the sectoral distribution of lobbying activities, we argue that lobbying on migration is substantially more concentrated in a few sectors than lobbying on trade. Finally, we observe that a similar pattern emerges when we examine the contributions of individual organizations.

The rest of the paper is organized as follows. Section 2 reviews papers in the literature which focus on the political economy of migration policy in general and, in particular, on the role played by interest groups. Section 3 describes the dataset on lobbying expenditures on migration. Section 4 carries out the descriptive analysis of the dataset on lobbying expenditures. Finally, Section 5 concludes.

\footnotetext{
${ }^{18}$ See for example Goldberg and Maggi (1999) and Gawande and Bandyopadhyay (2000).
} 


\section{Related Literature}

The literature on the political economy of migration policy is very thin and mainly theoretical. Benhabib (1996), Ortega (2005) and Facchini and Testa (2009) develop models in which migration policy is the outcome of majority voting, while Facchini and Willman (2005) and Epstein and Nizan (2006) theoretically focus on the role played by pressure groups.

In a seminal contribution, Benhabib (1996) considers the human capital requirements that would be imposed on potential immigrants by an income-maximizing polity under majority voting. Output is modeled using a constant returns to scale production function combining labor with human and/or physical capital. The median voter chooses to admit individuals who supply a set of factors that are complementary to her own endowment. As a result, if the median voter is unskilled, he will choose a policy that sets a lower bound on the human-capital labor ratio of the immigrants, that is only skilled foreigners will be admitted. On the other hand, if the median voter is highly educated, he will set an upper bound on the skill level of the immigrants, and thus will be in favor of admitting only individuals with low levels of education. Since in practice it is difficult to enforce this upper bound, the policy chosen by a skilled median voter is likely to be free migration. The main shortcoming of this analysis is that the constant returns to scale assumption might lead to counterintuitive results. In fact, while the optimal policy prescribes bounds on the skill profiles of the individuals to be admitted, it does not say anything about the actual size of the inflows. This is clearly at odds with the policies followed by countries around the world.

A different solution to this problem has been proposed by Ortega (2005), who extends Benhabib's model to a dynamic setting to explore the trade off between the short run economic impact of immigration and its medium to long run political effect. ${ }^{19}$ In particular, while immigration has an effect only on the labor market in the current period, in the future it also shapes the political balance of the destination country, as the descendants of migrants gain the right to vote. As a result, on the one hand, skilled natives prefer an immigration policy that admits unskilled foreign workers since, due to complementarities in production, this policy increases skilled wages. On the other, the

\footnotetext{
${ }^{19}$ See also Ortega (2010).
} 
arrival of unskilled immigrants and the persistence of skill levels across generations can give rise to a situation in which unskilled workers gain the political majority and, therefore, vote for policies that benefit them as a group. Thus, through the political channel, skilled natives (and a skilled median voter) prefer an immigration policy that admits skilled foreign workers. The interplay between these two forces allows Ortega to characterize the equilibrium migration quotas, i.e. to derive a prediction in terms of the size of migration inflows.

The paper that is most closely related to our analysis is Facchini and Willmann (2005). Using the menu auction framework pioneered by Bernheim and Whinston (1986), the authors model the determination of policies towards international factor mobility as the result of the interaction between organized groups and an elected politician. Using a one-good multiple factors framework, the model highlights how policies depend on both whether a production factor is represented or not by a lobby and on the degree of substitutability/complementarity between factors.

A small theoretical literature has also emerged explicitly modeling the role played by organized groups in shaping migration policy in a setting with imperfectly competitive factor markets. Amegashie (2004) models migration policy as the result of an all pay auction in which the auctioneer is represented by the government and the participants are a firm and a union. Bellettini and Berti Ceroni (2008) consider instead a model in which entrepreneurs and a union interact with an elected politician to determine the number of foreign workers to be admitted. Their main result is that, if the government chooses the level of immigration to maximize a weighted average of the welfare of workers and entrepreneurs, the presence of a union ends up hurting the very same workers which the union is meant to represent and protect. This result is based on a second best argument: the government attempts to reduce the labor market distortion introduced by the union by allowing a number of immigrants in the country that is larger than the one it would have admitted in the presence of a competitive labor market. This leads to a reduction in the union wage that can no longer compensate workers for the unemployment risk generated by the presence of the union.

From an empirical point of view, very few papers focus on political-economy determinants of migration policy. Facchini and Steinhardt (2011) investigate the 
determinants of the voting behaviour of House members on immigration policy measures introduced in the United States between 1973 and 2006. This paper uncovers the important role played by the labor market characteristics of the district electing the representative. Other studies investigate the role of lobbying, using data at the industry or occupational level. Facchini, Mayda and Mishra (2011) offer the first systematic empirical analysis of the role of interest groups in shaping contemporary U.S. migration policy. Using a newly available dataset for the years between 2001 and 2005, in which lobbying expenditures can be directly linked to immigration policies, the paper finds that sectors where pro-immigration business groups are more active (i.e. contribute more) tend to be allocated a larger number of work and related visas. On the other hand, in sectors in which anti-immigration labour unions are more powerful, lower numbers of immigrants are admitted. The estimates of the paper suggest that a $10 \%$ increase in the size of migration lobbying expenditures (per native worker) by business groups is associated with a 3.1\% larger number of visas (per native worker), while a onepercentage-point increase in union density - for example, moving from 10 to 11 percentage points, which amounts to a $10 \%$ increase in the union membership rate reduces it by $3.1 \%$. The results are robust to endogeneity concerns, which are addressed by introducing a number of industry-level control variables (e.g. output, prices, origin country effects, etc.), by performing a falsification exercise and, finally, by using an instrumental-variable estimation strategy.

Facchini and Mayda (2008) focus, instead, on cleavages across occupation/skill lines, rather than across sectors. Using a panel covering the period 1994-2005 and differentiating labour according to both skill levels and occupations, the paper finds systematic evidence suggesting that the lobbying activity of organized labour leads to a reduction in the inflow of foreign workers in the same occupation/education cell - this effect is driven by substitutability - and to an increase in the inflow of foreign workers in different occupation/education cells - this effect is driven by complementarity. This suggests that, for example, politically-organized doctors will lobby the government and succeed in decreasing the number of foreign doctors to the U.S. and in increasing the number of foreign nurses. Another paper that provides indirect empirical evidence on the role played by lobbying in shaping U.S. migration policy is Hanson and Spilimbergo 
(2001). Hanson and Spilimbergo (2001) focus on U.S. border enforcement and show that it softens when sectors using illegal immigrants expand. The authors suggest that "sectors that benefit greatly from lower border enforcement, such as apparel and agriculture, lobby heavily on the issue, while remaining sectors that benefit modestly or not at all are politically inactive." (page 636).

Finally, unlike other empirical studies which focus on the effect of lobbying on outcomes, Kerr, Lincoln, and Mishra (2013) analyze the determinants of lobbying and are among the first to provide systematic evidence on the dynamics of lobbying activities. The paper finds evidence of persistence, i.e. whether or not a firm lobbied in the past has a significant effect on whether it lobbies in the current period. A priori, there are reasons to believe that lobbying should exhibit significant entry and exit over time. ${ }^{20}$ However, this is not what the authors find. The authors argue that this persistence is due to barriers to entry into lobbying that firms face. They assess this argument using a number of different estimation approaches. They also study how firms respond to a predetermined policy change, i.e. the expiration of the increase in the H-1B visa cap that occurred in 2004. The data shows that firms dependent on skilled immigration and active in lobbying adjust their lobbying behaviour towards immigration-specific issues in response to the decline. On the other hand, firms that were not previously lobbying do not start lobbying in response to the policy shift.

To conclude, very few works have focused on the political economy of migration policy, especially from an empirical point of view. This is even more surprising if we compare migration to another facet of international economic integration, namely international trade. A vast theoretical and empirical literature considers the politicaleconomy determinants of trade policy, trying to understand the forces that work against and in favor of free trade. ${ }^{21}$ This is despite the fact that, as trade restrictions have been

\footnotetext{
${ }^{20}$ For example, the maxim that "a week is a lifetime in politics" suggests that firms might only lobby when legislation directly affecting them is actively being considered.

${ }^{21}$ See Rodrik (1995), Helpman (1997) and Gawande and Krishna (2003) for excellent surveys of the trade literature.
} 
drastically reduced, the benefits from elimination of existing trade barriers are much smaller than the gains that could be achieved by freeing international migration. ${ }^{22}$

\section{Data on lobbying expenditures}

In the United States, special interest groups can legally influence the policy formation process by offering campaign contributions to political candidates for election purposes or by hiring organizations which lobby incumbent members of Congress and of federal agencies on their behalf. Starting already in 1911, after a vigorous campaign initiated by President Theodore Roosevelt to limit the influence of business in politics, legislation was passed to require disclosure of contributions directed to political candidates for campaign purposes (Ansolabehere, de Figueredo, and Snyder 2003). The data on campaign contributions have been widely used in the political science and international economics literatures and are collected by the Federal Election Commission.

The activities of lobbying organizations have instead remained much more obscure. Only in 1995, with the introduction of the Lobbying Disclosure Act (LDA), lobbying organizations and their clients have been required to provide a substantial amount of information on their government relations activities. In particular, starting from 1996 all lobbyists must file semi-annual (and more recently quarterly) reports with the Secretary of the Senate's Office of Public Records (SOPR), listing the name of each client (either a firm, a labor union or other organization ${ }^{23}$ ) and the total income they have received from each of them. At the same time, all lobbying organizations with in-house lobbying departments are asked to file similar reports to the SOPR. Importantly, legislation requires the disclosure not only of the dollar amounts actually received/spent, but also of the (general) policy issues for which lobbying has taken place. Table A1 in the Appendix shows a list of 76 (general) issues at least one of which has to be entered by the filer. The filer can list more than one issue. In that case, it has to use a separate page of the form for each code selected. The list of issues includes immigration (IMM), trade

\footnotetext{
${ }^{22}$ A World Bank study estimates that the benefits to poor countries of rich countries allowing only a 3 percent rise in their labor force by relaxing migration restrictions is US\$300 billion per year (Pritchett 2006).

${ }^{23}$ When we refer to either firms, labor unions or other organizations which hire lobbyists (either in house or externally), we will call them "lobbying organizations." On the other hand, we will call external lobbyists (for example those whose offices are located on K Street in Washington DC) "lobbying firms."
} 
(TRD), etc. ${ }^{24}$ For each general issue, the filer also may (but does not necessarily have to) list the specific issue(s) for which it lobbied during the semi-annual period (for example, specific issues could be particular bills before Congress or specific executive branch actions). ${ }^{25}$

Lobbying firms are required to provide a good-faith estimate, which can be rounded to the nearest $\$ 20,000$, of all lobbying-related income in each six-month period. Likewise, lobbying organizations with in-house lobbying departments are required to provide a good-faith estimate, which can be rounded to the nearest $\$ 20,000$, of all lobbying-related expenditures in a six-month period. A lobbying firm or lobbying organization that, respectively receives or spends less than $\$ 10,000$ in any six-month period, does not have to state its income or expenditures. If lobbying is not disclosed in such cases, the figure is reported by CRP as zero. However, as Kerr, Lincoln, and Mishra (2013) argue, the measurement error induced by reporting requirements is likely to be minimal.

The data on lobbying incomes/expenditures are compiled by CRP in Washington D.C. using the semi-annual lobbying disclosure reports filed with SOPR and posted to its website (www.crp.org). The reports used in this paper cover lobbying activity that took place from 1998 through 2005. Annual lobbying incomes and expenditures are calculated by adding mid-year totals and year-end totals. Whenever a lobbying report is amended, income/expense figures from the amendment are generally used instead of those from the original filing. Often, however, CRP staff determines that the income/expense figures on the amendment are not accurate. In those instances, figures from the original filing are used.

Occasionally, income that an outside lobbying firm reports receiving from a lobbying organization is greater than the organization's reported lobbying expenditures.

\footnotetext{
${ }^{24}$ Surprisingly, the list of issues also includes names of some industries, e.g. apparel, computer, tobacco etc.

${ }^{25}$ According to the Lobbying Disclosure Act, the term "lobbying activities" refers to "lobbying contacts and efforts in support of such contacts, including preparation and planning activities, research and other background work that is intended, at the time it is performed, for use in contacts, and coordination with the lobbying activities of others." Lobbying could take place by setting up an in-house lobbying department or by hiring external consultants. While setting up a whole office for in-house operations is likely more expensive, if a firm employs a lobbyist externally the new hire still has to spend a significant amount of time learning the particular needs and characteristics of their new client and how items currently on the agenda will affect them specifically.
} 
Many such discrepancies can be explained by the fact that the lobbying organization and the outside lobbying firm use different filing methods (see Appendix at the end of the paper for a detailed description of different filing methods). When both organizations use the same method, discrepancies are generally due to filer error. In cases not already resolved in previous reports and where the discrepancy exceeds the $\$ 20,000$ that can be attributed to rounding, the lobbying organization's expenditures rather than the lobbying firm's reported income are used. The only exception is when an organization reports no lobbying expenditures, while the outside lobbying firm lists an actual payment. In such cases, the figure reported by the lobbying firm is used.

In cases where the data appear to contain errors, official Senate records are consulted and, when necessary, the CRP contacts SOPR or the lobbying organizations for clarification. The CRP standardizes variations in names of individuals and organizations to clearly identify them and more accurately represent their total lobbying expenditures. ${ }^{26}$

Table A2 in the Appendix shows a sample form filled by Microsoft for lobbying activity between January-June 2005. Only three selected pages of the form are shown in the appendix. Page 1 shows the name and details of Microsoft, the time period covered by the report (January 1 - June 30, 2005) and the expenses incurred by Microsoft for lobbying activity during this period (US\$4.5 million). ${ }^{27}$ The lobbying expenditure is listed once on the first page of the form and the amount is not split between the issues. Microsoft lists "Method C" as the reporting method, i.e. reported amounts use the Internal Revenue Code (IRC) definition of lobbying activities. This method is available to any registrant that is subject to Section 162(e) of the IRC (see Appendix at the end of the paper for a discussion of this point). ${ }^{28}$

The other two pages of the form in Table A2 show two general issues for which Microsoft engaged in lobbying activity during the six-month period - immigration

\footnotetext{
${ }^{26}$ Please note that, in our dataset, lobbying organizations only appear once in each year. In addition, in cases where both a parent and its subsidiary organizations lobby or hire lobbyists, the Center attributes lobbying spending to the parent organization. Therefore, the lobbying totals reported by the Center for a parent organization may not reflect its original filing with the Senate, but rather the combined expenditures of all related entities. Moreover, when companies merge within any two-year election cycle, their lobbying expenditures are combined and attributed to the new entity.

${ }^{27}$ Note that each report contains only an indication of the total spent by the organization, and not of the amount spent for a specific issue. For details on how we compute our estimates of the amounts contributed for each purpose, see Section 4.

${ }^{28}$ The grass-roots and state lobbying expenses are not subtracted from this amount.
} 
(IMM) and trade (TRD). Microsoft lists seven other issues in its report - e.g., taxation (TAX) - which are not shown in the appendix table. For immigration, the specific issues listed by Microsoft are H-1B visas, L-1 visas and Program Electronic Review Management (PERM) regulations. For trade, some of the specific issues listed include the Dominican Republic-Central America-United States FTA Implementation Act, software piracy and procurement issues in China, interpretation and enforcement of the WTO agreement on intellectual property (TRIPS), etc.

As mentioned in the Introduction, the availability of lobbying expenditure data allows for a significant improvement in the measurement of the intensity of pressure groups' activities compared to the previous literature which has used, instead, political action committees (PAC) campaign contributions. As shown in Table 1, between 1999 and $2004^{29}$, interest groups have spent on average about 3.8 billion U.S. dollars per political cycle on targeted political activity, which includes PAC campaign contributions and lobbying expenditures. ${ }^{30}$ Lobbying expenditures represent by far the bulk of all interest groups money (close to ninety percent). ${ }^{31}$ Therefore, there are two advantages in using lobbying expenditures rather than PAC contributions to capture the intensity of the activity of pressure groups. First, PAC contributions represent only a small fraction of interest groups' targeted political activity (10 percent). Second, linking campaign contributions to particular policy issues is very difficult and often requires some ad-hoc assumptions. ${ }^{32}$ Overall, our data suggest that immigration and trade are two significant issues over which pressure groups carry out their activities, representing together between

\footnotetext{
${ }^{29}$ Table 1 and Figure 1 are based on data for the full political cycles included in our sample period, i.e. the 1999-2000, the 2001-2002 and the 2003-2004 political cycles.

${ }^{30} \mathrm{We}$ follow the literature that excludes, from targeted-political-activity figures, "soft money" contributions, which went to parties for general party-building activities not directly related to Federal campaigns; in addition, soft money contributions cannot be associated with any particular interest or issue (see Milyo, Primo, and Groseclose 2000 and Tripathi, Ansolabehere, and Snyder 2002). Soft money contributions have been banned by the 2002 Bipartisan Campaign Reform Act.

${ }^{31}$ In a recent survey of the literature de Figueredo and Richter (2014) argue that, in the 2011-2012 political cycle, PAC contributions amounted to approximately 750 million dollars per year, whereas the total lobbying expenditures by organized groups reached 3.5 billion dollars. In other words, while the latter continue to represent the vast majority of interest groups money, the most recent figures suggest that PAC contributions have become relatively more important, representing approximately eighteen percent of the total.

${ }^{32}$ For instance, in their pioneering work on the estimation of Grossman and Helpman (1994) protection for sale model, Goldberg and Maggi (1999) have used threshold levels for PAC expenditures to identify whether a sector is politically organized or not, from the point of view of trade policy determination.
} 
4.5 and 5.9 percent of the total lobbying expenditures in the political cycles covered in our analysis (see Table 1).

The importance of complementing the PAC data with the lobbying data can be seen by examining the three scatter plots illustrated in Figure 1 - which is based on averages over the three election cycles that occurred between 1999 and 2004. The first links overall lobbying expenditures (i.e. on all issues) and PAC contributions; the second depicts the relationship between lobbying expenditures associated with immigration policy $^{33}$ and PAC contributions, whereas the third illustrates the link between lobbying expenditures on trade policy and PAC contributions. A few interesting patterns emerge. The first panel shows a positive and significant correlation between overall (i.e., on any issue) lobbying expenditures and PAC contributions across sectors. This result is consistent with findings in the political science literature suggesting that PAC contributions are integral to groups' lobbying efforts, i.e. they allow them to gain access to policymakers (Tripathi, Ansolabehere, and Snyder 2002). A similar pattern can be also identified while looking at the relationship between lobbying on trade policy and PAC contributions (see also Ludema, Mayda and Mishra 2011). In contrast, the very low correlation between PAC contributions and lobbying expenditures for migration policy, emerging from the central panel, is striking. It suggests that, if we were to use only the data on PAC contributions as a proxy for interest groups' activity on migration policy, we would obtain misleading results. Further details about the construction of the dataset on lobbying expenditures are discussed in the Appendix.

\section{Descriptive analysis of the data on lobbying expenditures}

In this paper, we use data at the lobbying-organization-level on lobbying expenditures of lobbying organizations (i.e., firms, labor unions or other organizations) from the CRP dataset. In the case of a lobbying organization which "self-files" (i.e., an organization with an in-house lobbying department), the CRP uses the figure in its report, which includes both in-house and external lobbying expenditures for the period. In the case of an organization which does not "self-file," the CRP uses the sum of its contracts with outside lobbying firms to represent its lobbying expenditures for the period.

\footnotetext{
${ }^{33}$ In the terminology of the following section, these correspond to "total lobbying expenditures."
} 
Figures 2, 3 and 4 show the evolution of lobbying expenditures over time. Figure 2 shows "overall lobbying expenditures," while Figure 3 and 4 show respectively "total lobbying expenditures" and "lobbying expenditures" on migration and - as a benchmark - on international trade. ${ }^{34}$ The "overall lobbying expenditures" are given by the sum of lobbying-organization-level lobbying expenditures on any issue of all organizations active in lobbying in all industries, year by year. Thus, this is an indicator of how aggressively organizations carry out lobbying activity in general in the economy. The "total lobbying expenditures" (on immigration or trade) are equal to the sum of lobbying expenditures on any issue by organizations spending money on respectively migration or trade, in all industries, year by year. The "lobbying expenditures" (on immigration or trade) are instead equal to lobbying expenditures only on respectively migration or trade by organizations spending money on these issues, in all industries, year by year. "Lobbying expenditures" (on immigration or trade) are computed using a two-step procedure. First, only those organizations are considered which list respectively migration or trade in their lobbying report. Second, the total expenditure of these organizations is split equally among all the issues they lobbied for. ${ }^{35}$ "Lobbying expenditures" represent the most direct measure of lobbying activity related to the specific issue. On the other hand, "total lobbying expenditures" represent an upper bound of lobbying expenditures on the specific issue, since they also include all lobbying expenditures on other issues. The motivation for interpreting "total lobbying expenditures" as an upper bound of lobbying expenditures on respectively migration or trade is that lobbying expenditures are to a certain extent fungible across issues.

Overall lobbying expenditures have grown by more than $50 \%$ from US $\$ 1.4$ bn in 1998 to US\$2.3 bn in 2005. According to Figure 2, the increase has been steady over the years. Total lobbying expenditures on immigration have grown by approximately $15 \%$ from US\$196 mn in 1998 to US\$227 mn in 2005, whereas total lobbying expenditures on trade have increased by $32 \%$ from US\$564 $\mathrm{mn}$ in 1998 to US\$745 $\mathrm{mn}$ in 2005. Figure 3 shows an irregular pattern over the 1998-2005 period, but spending on immigration and

\footnotetext{
${ }^{34}$ Figures 3 and 4 use data from the fourth column (sum) of Tables 2 and 4, respectively.

${ }^{35}$ Recall that the lobbying expenditure of a firm is listed only once in the lobbying report, on the first page, and the reported amount is not split between the issues the firm lobbies for. Thus, to be as neutral as possible, in the empirical analysis we split the total amount on the first page equally among issues.
} 
trade appear to be positively correlated. Finally, according to Figure 4, lobbying expenditures on migration have grown by more than 25 percent from US\$18 mn in 1998 to US\$23 $\mathrm{mn}$ in 2005 , whereas lobbying expenditures on trade have increased by more than 50 percent over the same time period, i.e. from US\$60 mn in 1998 to US\$92 $\mathrm{mn}$ in 2005. Figure 4 shows again an irregular pattern over time and the correlation between expenditures on immigration and trade is lower when we use this measure.

It is not clear how to interpret the fact that interest groups' activity on migration was lower in 2003, compared to 2000 (see Figures 3 and 4). One possibility is that this decrease is due to the September 11 attacks, which likely affected migration politicaleconomy dynamics. In other words, it might be that lobbying expenditures on migration reacted to (decreased due to) the new political climate in the U.S.. Alternatively the decrease in lobbying activity over 2000-2003, followed by the increase in 2004-2005, could be related to the changes in the H-1B visa quotas over those years. The national cap in $\mathrm{H}-1 \mathrm{~B}$ visas was 115,000 in 2000, 195,000 in 2001-2003, 65,000 in 2004 and 85,000 in 2005. Thus we can identify a major break in migration policy in 2004 , with policy being much more open in 2000-2003 and much more closed in 2004-2005. Thus these few years of data suggest that lobbying expenditures on migration were low in the years in which the H-1B cap was high and vice versa. However, it is also possible to interpret the data as suggesting that the $\mathrm{H}-1 \mathrm{~B}$ cap was high when previous years' lobbying expenditures on migration were high and vice versa. Both the robustness of these patterns and the direction of causality are beyond the scope of this paper and should be analyzed in future research (see, for example, Kerr, Lincoln and Mishra 2013).

Tables 2, 3, and 4 provide more detailed information on lobbying activity on immigration and trade, year by year. These tables focus on the restricted sample of organizations which indicated immigration (or trade) as an issue in their lobbying report in the years included between 1998 and 2005. Over the entire period, organizations lobbied for migration purposes 1662 times (some of these observations correspond to the same lobbying organization in different years), whereas they did so 6143 times for trade issues, i.e. approximately four times more often. For example, in 1998 there were 220 (642) organizations which hired lobbyists (in house or external) for migration (trade) purposes. These numbers went up and down over the years but do show an overall 
positive trend. According to Table 2, over this period, on average a firm in this sample spent approximately US\$790,000 on lobbying on migration in a given year, and slightly more than that on trade, i.e. US\$810,000. Note that these numbers - as clarified above include lobbying on any issue by these organizations ("total lobbying expenditures"), i.e. they are an upper bound of how much an organization in this sample spent to influence these two policy areas. Table 3 gives instead information, more specifically, on "lobbying expenditures" on migration and trade of the same group of organizations. Over this period, on average an organization in this sample spent approximately US\$78,000 on migration in a given year and US\$97,000 on trade policy in a given year. We will focus our comments on Table 3 since it provides the most direct evidence on migration and trade lobbying. Between 1998 and 2005, a total of US\$130mn were spent on lobbying specifically targeted at shaping US migration policy and US\$598mn to shape trade policy.

Table 4 focuses on an even more restricted sample, i.e. lobbying organizations spending only on immigration or trade. In other words, these are the organizations which indicate only, respectively, migration or trade in their lobbying report. Over the 19982005 period, organizations lobbied only on migration 98 times, and only on trade 621 times. For example, in 1998 there were 12 organizations who hired lobbyists exclusively for migration purposes, whereas $63 \mathrm{did}$ so for trade. This number went up to 18 in 2005 for migration and to 97 for trade. On average, between 1998 and 2005, organizations spending only on immigration disbursed approximately US\$120,000 in a given year, whereas the corresponding figure for lobbying only on trade was slightly higher at US $\$ 132,000$. If we compare these numbers to the corresponding numbers in Table 3, we can see that lobbying expenditures on migration of organizations exclusively interested in migration are higher than for organizations doing lobbying on migration and other issues (and the same holds true for trade). The numbers in Table 4 are important because they give us the exact expenditure on respectively migration and trade of organizations which exclusively lobby on these issues, therefore these values are not affected by even splitting (see footnote 26).

The Center for Responsive Politics (CRP) matches each lobbying organization in its dataset to an industry. (Note that it is CRP that assigns aggregator groups to different 
sectors in the analysis. For example, the U.S. Chamber of Commerce is assigned to the industry "business associations," which is the case for other aggregator groups, like the National Federation of Independent Business and the Alliance for Health Care Competitiveness.) Tables 5, 6, 7 and 8 show summary statistics by sector - using the CRP industry classification - on average over the 1998-2005 period. These tables again focus on the restricted sample of lobbying organizations which wrote down respectively immigration or trade as an issue in their lobbying report. Table 5 presents "total lobbying expenditures" while Table 6 shows "lobbying expenditures." In both tables, we present industries ranked by the "sum" column, i.e. the column that gives the total expenditure in each sector over the period. We will focus our discussion on Table 6 .

Several interesting results emerge in Table 6 . First, Table 6 shows clearly who the top spenders are - among industries - in terms of lobbying on respectively immigration or trade between 1998 and 2005. Moreover, it also allows us to study how concentrated lobbying activities are. Calculating the CR4 index, ${ }^{36}$ we can see that the four most active sectors represent approximately 29 percent of the total expenses on migration. Turning to trade, they represent approximately 21 percent of the total, suggesting that lobbying on this issue is substantially more diffused than lobbying on migration.

Computers/Internet is the very top spender on lobbying for both issues over the period considered. The Computers/Internet industry spent approximately a total of US\$16.8mn on migration and a total of US\$38.5mn on trade in the years 1998-2005. Over the same period, on average a firm in this industry spent US\$136,000 for lobbying on immigration in a given year, ${ }^{37}$ and US $\$ 118,000$ for lobbying on trade.

Among the top spenders on migration, we also find Education, Air Transport, Automotive, Hospitals/Nursing Homes, Miscellaneous Manufacturing \& Distributing, and Agricultural Services/Products. The patterns in this table are consistent with anecdotal evidence. Except for the Air Transport industry, these are all sectors which use large numbers of immigrants. For example, many university professors and researchers are foreign-born. There is great demand for foreign nurses in the United States given the

\footnotetext{
${ }^{36}$ The CR4 index is a measure of concentration. In our context it is defined as lobbying carried out by the four top lobbying sectors as a share of the total lobbying on a given issue.

${ }^{37}$ Note that each of the 123 observations for the Computers/Internet industry in Table 6 corresponds to a given lobbying organization in a given year (thus, if an organization files in two different years, it counts twice).
} 
low supply of native-born nurses. Finally, the agricultural sector is completely dependent on the work of immigrant (unskilled) labor. Note though that only Air Transport and Automotive appear also among the top ten spenders on trade policy, highlighting the presence of important differences in the relevance of trade and immigration for specific sectors of the economy.

Interestingly, Table 6 highlights that the sector with the highest number of "organizations" lobbying on migration over the period is Education: in 1998-2005, universities/educational institutions carried out lobbying activity on migration 296 times (some of these observations correspond to the same university in different years). For example, Harvard University, Georgetown University, New York University, etc. are all in the dataset, often for multiple years. However, on average, between 1998 and 2005, a university/educational institution did not spend much on migration lobbying in a given year (approximately US $\$ 23,000$ ).

The two panels of Table 7 (like Table 4) focus on a more restricted sample, i.e. "organizations" spending lobbying money only on respectively immigration (panel a) or trade (panel b). In other words, these are the organizations which indicate only respectively migration or trade as a policy issue in their lobbying report. Table 7 presents the amounts of lobbying expenditures on migration for these organizations, industry by industry, in the 1998-2005 period. One of the industries with organizations carrying out lobbying activity exclusively on migration is Human Rights, where we observe 11 instances in which money was spent for this purpose. This selected group of organizations in the Human Rights industry spent a total of US $\$ 1.8 \mathrm{mn}$ on lobbying for migration. Since migration is the only policy issue in the reports of these organizations, we know for sure that all this money was targeted at shaping migration policy. Turning to trade policy, we can see that Forestry and Forest Products and Steel production were industries with organizations lobbying exclusively on trade policy, spending respectively a total of US\$10.1 mn and US\$9.2 $\mathrm{mn}$ on lobbying for trade. Interestingly, lobbying activity on trade took place much more frequently, i.e. 28 and 58 times respectively.

Finally, in Tables 8 and 9, we focus more directly on data at the lobbyingorganization level. First, notice that lobbying on trade and migration is positively correlated at the lobbying-organization level (Figure 5). In Table 8, we collapse the data 
on "total lobbying expenditures" and "lobbying expenditures" on respectively migration and trade across years at the lobbying-organization level. In other words, we sum the values of the two variables, respectively, from all the lobbying reports corresponding to a given organization across all the eight years between 1998 and 2005. Table 8 shows the top 50 organizations in terms of lobbying expenditures on respectively migration and trade in 1998-2005.

Note that the main difference between Table 6 and Table 8 is that Table 6 provides information at the year-lobbying-organization level on average for each industry while Table 8 gives information at the lobbying-organization level summed over the eight years. So, for example, the US\$136,511 value for the average in the Computers/Internet industry in Table 6 gives the average amount spent by a lobbying organization - for lobbying on immigration - in this sector in one year between 1998-2005. On the other hand, the US\$3,564,231 value for "lobbying expenditures on migration" for Microsoft Corporation in Table 8 gives the sum of expenditures on migration by Microsoft in all the eight years.

As already argued while discussing the sector-level results of Table 6, lobbying on migration appears to be substantially more concentrated than lobbying on trade. In the former case, the top 4 organizations contributed about 9 percent of the total amount spent on migration, whereas the top 4 contributed only 5 percent of the total spent on trade. The organization in the dataset which invested the largest amount on lobbying on migration over the eight years is Microsoft Corporation which, as mentioned above, spent approximately US\$3.6 $\mathrm{mn}$ to affect migration in this period. Among the top 50 organizations, we also find the American Farm Bureau Federation and the National Council of Agricultural Employers, the American Hospital Association, Disney Worldwide Services and, finally, also labor unions (United Auto Workers and the AFLCIO). Turning to lobbying on trade, the right panel of Table 8 shows that the US Chamber of Commerce was the top spender on the issue, with a total of US $\$ 10.4 \mathrm{mn}$. The leading defense contractor Northrop Grumman was also very active in trying to shape US trade policy. This is not surprising given the sensitive nature of a substantial share of the firm's production. Turning to information using data from lobbying reports where only migration or trade appear as an issue, Table 9 shows that the majority of the organizations 
in these categories are either trade associations or ideology-issue groups, ${ }^{38}$ and not corporations.

\section{Conclusions}

In this paper, we have used a lobbying-organization-level dataset of lobbying expenditures, covering the period between 1998 and 2005, and have analyzed lobbying activity specifically targeted at shaping immigration and trade. The dataset uses information from lobbying reports which organizations involved in lobbying have to file since 1996, after the passage of the 1995 Lobbying Disclosure Act.

Several interesting points emerge from our analysis. First, while PAC contributions and lobbying are in general positively correlated, our results suggest that this is not the case when it comes to lobbying on migration. As a result any analysis that focuses on the role of pressure group activity in affecting migration should take advantage of the rich new data on lobbying, rather than relying only on PAC contribution data. Second, while overall lobbying expenditures increased steadily over our sample period, both lobbying on migration and trade appears to fluctuate more. Third, the total amount spent on lobbying for immigration and trade never exceeded 6 percent of the total lobbying contributions, and the total amount contributed with the purpose of shaping trade policy was typically four to six times larger than the amount contributed to shape migration policy (see Table 1). Fourth, turning to the sectoral distribution of lobbying activities, we have argued that lobbying on migration is substantially more concentrated than lobbying on trade. Finally, we have seen that a similar pattern emerges also when we examine the contributions of individual organizations.

The analysis carried out in this paper is mainly descriptive and has allowed us to highlight some important similarities and differences in the patterns of lobbying on two facets of globalization, international migration and international trade. Neoclassical economic theory in the spirit of Heckscher and Ohlin suggests that trade and migration are substitutes, yet we have documented the existence of significant differences in the extent of pressure groups organization on these two issues, ranging from the amount of

\footnotetext{
${ }^{38}$ For a discussion on the role played by ideology-issue groups and corporations and trade associations, see de Figueredo and Richter (2014).
} 
resources invested, to the number of organizations involved in lobbying, to the sectors in which these organizations are active. One interesting question that could be addressed using our data is to what extent are there differences in the returns to lobbying in these two areas. In other words, are greater monetary payoffs the main explanation for why lobbying on trade is more widespread than lobbying on migration? A second important question would instead focus on the extent to which organizations perceive migration and trade policy as political complements or substitutes. While answering these questions would enhance our understanding of the political economy of globalization, they go beyond the scope of this paper and are left for further research.

\section{Bibliography}

Amegashie, J. A. (2004). "A political economy model of immigration quotas," Economics of Governance 5, 255-267.

Ansolabehere, S., J. de Figueredo, and J. Snyder (2003). "Why is there so little money in US politics?” Journal of Economic Perspectives 17, 105-130.

Bellettini, G. and C. Berti Ceroni (2008). "Can unions hurt workers? A positive analysis of immigration policy," Economics and Politics 20, 106-124.

Benhabib, J. (1996). “On the political economy of immigration," European Economic Review 40, 1737-1743.

Bernheim, B. D. and M. D. Whinston (1986). "Menu auctions, resource allocation, and economic influence," Quarterly Journal of Economics 101, 1-31.

Borjas, George J. 1995. "The Economic Benefits from Immigration," Journal of Economic Perspectives 9, 3-22.

de Figueredo, John and B. K. Richter (2014). "Advancing the Empirical Research on Lobbying," Annual Review of Political Science 17, 163-185.

Epstein, G. and S. Nitzan, (2006). "The Struggle over Migration Policy," Journal of Population Economics 19, 703-723.

Facchini, G. and A. M. Mayda (2008). "From individual attitudes towards migrants to migration policy outcomes: Theory and evidence," Economic Policy 56, 651-713.

Facchini, G., Mayda, A. M. and P. Mishra (2011). "Do interest group affect US immigration policy?", Journal of International Economics 85, 114-128.

Facchini, G. and M. F. Steinhardt (2011). "What drives US immigration policy? Evidence from Congressional roll call votes," Journal of Public Economics 95, 734-743.

Facchini, G. and C. Testa (2009). "Who is against a common market?" Journal of the European Economic Association 7, 1068-1100 
Facchini, G. and G. Willmann (2005). "The political economy of international factor mobility," Journal of International Economics 67, 201-219.

Freeman, G. (1992). "Migration Policy and Politics in the Receiving States," International Migration Review 26, 1144-1167.

Gawande, K. and U. Bandyopadhyay (2000). "Is protection for sale? Evidence on the Grossman-Helpman theory of endogenous protection," Review of Economics and Statistics 82, 139-152.

Gawande, K. and P. Krishna (2003). "The political economy of trade policy: Empirical approaches," in E. Choi and J. Harrigan (Eds.), Handbook of International Trade, 213250, Oxford, Blackwell Publishing.

Goldberg, P. K. and G. Maggi (1999). "Protection for sale: An empirical investigation," American Economic Review 89, 1135-55.

Goldin, C. (1994). "The political economy of immigration restriction in the United States, 1890 to 1921," in C. Goldin and G. Libecap (Eds.), The Regulated Economy: A Historical Approach to Political Economy, 223-257. Chicago, IL: University of Chicago Press.

Goldsborough, J. (2000). “Out-of-control immigration,” Foreign Affairs 79, 89-101.

Grossman, G. M. and E. Helpman (1994). "Protection for sale," American Economic Review, 84, 833-850.

Hanson, G. H. and A. Spilimbergo (2001). "Political economy, sectoral shocks and border enforcement," Canadian Journal of Economics 34, 612-638.

Helpman E. (1997). "Politics and trade policy," in D.M.Kreps and K.F.Wallis (Eds.) Advances in Economics and Econometrics: Theory and Applications, 1, 19-45. Cambridge University Press, Cambridge UK.

Joppke, L. (1998). "Why Liberal States Accept Unwanted Immigration," World Politics 50, 266-293.

Kerr, W., W. Lincoln and P. Mishra, (2013). "Dynamics of Firm Lobbying," forthcoming, American Economic Journal, Economic Policy.

Ludema, R., A.M. Mayda and P. Mishra (2011). "Protection for Free? The Political Economy of U.S. Tariff Suspensions," mimeo Georgetown University.

Mayda, A. M. (2006). "Who Is Against Immigration? A Cross-Country Investigation of Individual Attitudes toward Immigrants," Review of Economics and Statistics 88, 510530.

Milyo, J., D. Primo, and T. Groseclose (2000). "Corporate PAC campaign contributions in perspective," Business and Politics 2, Art. 5.

Ortega, F., (2010). "Immigration, Citizenship, and the Size of Government," The B.E. Journal of Economic Analysis \& Policy: Vol. 10(1), Contributions, Art. 26.

Ortega, F. (2005). "Immigration policy and skill upgrading," Journal of Public Economics 89, 1841-1863. 
Pritchett, L. (2006). "Let their people come," Washington, DC: Brookings Institution Press.

Rodrik, D (1995). "Political Economy of Trade Policy," in G. Grossman and K. Rogoff (Eds.) Handbook of International Economics, vol. 3, , 1457-1494. Amsterdam, NorthHolland.

Timmer, A. and J. Williamson (1996). "Racism, xenophobia or markets? The political economy of immigration policy prior to the Thirties," NBER WP 5867.

Tripathi, M., S. Ansolabehere, and J. Snyder (2002). "Are PAC contributions and lobbying linked? New evidence from the 1995 Lobby Disclosure Act," Business and Politics, 4, 131-155. 


\section{Appendix: Details about lobbying expenditures data}

In addition to campaign contributions to political candidates for election purposes, each year companies, labor unions, and other organizations spend billions of dollars to hire lobbying firms which lobby incumbent members of Congress and of federal agencies on their behalf. Some special interests hire external lobbying firms; others have lobbyists working in-house.

The data on lobbying expenditures are compiled by the Center for Responsive Politics (CRP) using the semi-annual lobbying disclosure reports filed with the Secretary of the Senate's Office of Public Records (SOPR) and posted to its website. The reports analyzed by CRP cover lobbying activity that took place from 1998 through 2005.

The Lobbying Disclosure Act (LDA) of 1995 requires lobbying firms and organizations to register and to file reports of their lobbying activities with the SOPR. In general, it requires registration by any individual lobbyist (or the individual's employer if it employs one or more lobbyists) within 45 days after the individual first makes - or is employed or retained to make - a lobbying contact with either the President, the Vice President, a Member of Congress, or any other specified Federal officer or employee, including certain high-ranking members of the uniformed services.

A registrant must file a report for the semiannual period when registration initially occurs and for each semiannual period thereafter, including the period during which registration terminates. Lobbying firms (i.e., entities with one or more lobbyists, including self-employed individuals who act as lobbyists for outside clients) are required to file a separate report for each client covered by a registration. Organizations employing in-house lobbyists file a single report for each semiannual period. The semiannual report must be filed no later than 45 days after the end of a semiannual period beginning on the first day of January and the first day of July of every year in which a registrant is registered. The LDA requires the Secretary of the Senate and the Clerk of the House of Representatives to make all registrations and reports available to the public as soon as practicable after they are received.

Under the Section 3(10) of the LDA, an individual is defined as a "lobbyist" with respect to a particular client if he or she makes more than one lobbying contact on behalf 
of that client (i.e. more than one communication to a covered official) and his or her "lobbying activities" constitute at least 20 percent of the individual's time in services for that client over any six-months period. "Lobbying activity" is defined in Section 3(7) of the LDA as "lobbying contacts or efforts in support of such contacts, including background work that is intended, at the time it was performed, for use in contacts, and coordination with the lobbying activities of others."

Section 15 of the LDA permits those organizations that file under Sections 6033(b)(8) of the Internal Revenue Code (IRC) and organizations that are subject to Section 162(e) of the IRC to use the tax law definitions of lobbying in lieu of the LDA definitions for determining "contacts" and "lobbying activities". The definition of lobbying in the tax law is broader with respect to the type of activities reported, while it is narrower with respect to the executive branch officials who are contacted. For example, the definition of lobbying under the tax code includes "grass-roots", state and local lobbying, while the LDA excludes these types of lobbying from the definition of "lobbying activities." Under the amendment of the LDA in 1998, registrants who use tax law definitions of lobbying must use the IRC definition for executive branch lobbying and the LDA definition for legislative branch lobbying.

There are three different filing methods listed in the form. Two options are largely identical (one for for-profit groups, the other for non-profit groups) and use the definition of lobbying provided by the IRC. The third follows the definition of lobbying contained in the LDA. As discussed above, filers using the IRC methods must report state, local and grassroots lobbying costs, which are not included in the reports which follow the LDA definition. Thus, lobbying expenditures may not be strictly comparable across organizations using different filing methods. 
Table 1. Targeted Political Activity

(in millions of US dollars)

\begin{tabular}{|lrrr|}
\hline \multicolumn{1}{c}{ (in millions of US dollars) } & & \\
\hline Election cycle & $\mathbf{1 9 9 9 - 2 0 0 0}$ & $\mathbf{2 0 0 1 - 0 2}$ & $\mathbf{2 0 0 3 - 0 4}$ \\
\hline Contributions from PACs & 326 & 348 & 461 \\
Overall lobbying exp & 2,949 & 3,330 & 4,048 \\
$\quad$ Of which exp for immigration & 32 & 24 & 33 \\
Of which exp for trade & 143 & 153 & 150 \\
\hline Total targeted political activity & 3,275 & 3,678 & 4,509 \\
\hline \hline
\end{tabular}

Source: Center for Responsive Politics. Overall lobbying exp are equal to the sum of lobbying expenditures of all firms on any issue. Exp for immigration (trade) are equal to lobbying expenditures on migration (trade) of organizations spending money on immigration (trade).

Figure 1. Scatter Plots between Lobbying Expenditures and Campaign Contributions from PACs (mn US\$), 1999-2004

Overall lobbying expenditures

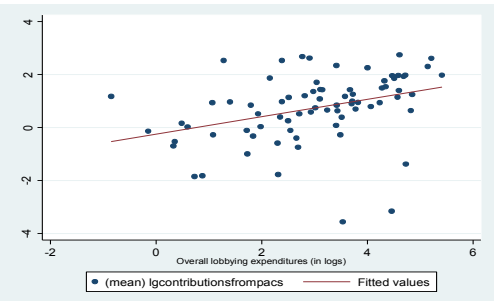

Immigration lobbying exp

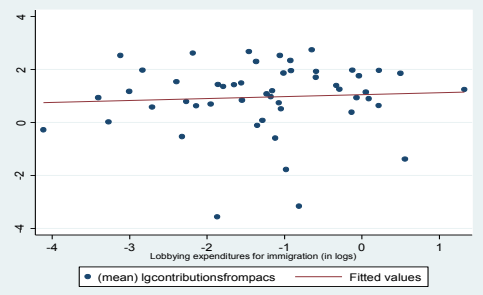

Trade lobbying exp

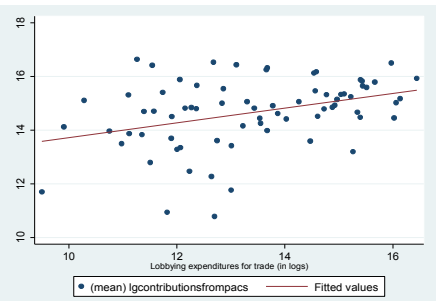

The "overall lobbying expenditures" are equal to the sum of firm-level lobbying expenditures on any issue of all firms/business associations/unions in all industries, year by year "Immigration lobbying expenditures" in the middle panel correspond to "total lobbying expenditures" in Figure 3. See end of Figure 3. Trade lobbying expenditures are defined as "total trade lobbying expenditures" 
Figure 2. Overall Lobbying Expenditures, year by year

(1998-2005)
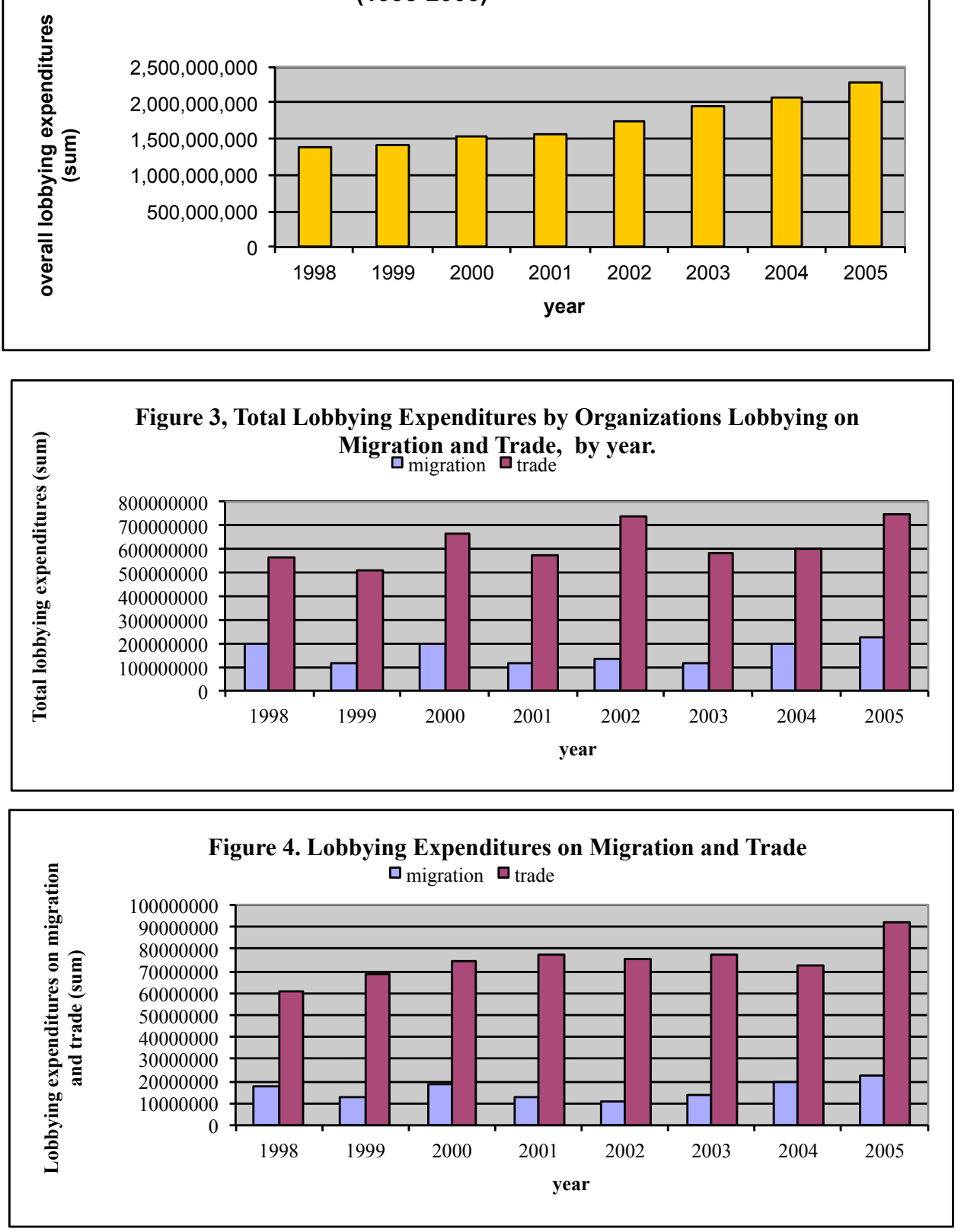

The "overall lobbying expenditures" are equal to the sum of lobbying expenditures on any issue of all organizations in all industries by year. The "total lobbying expenditures" are equal to the sum of lobbying expenditures on any issue of organizations spending money on immigration and trade in all industries, by year. The "lobbying expenditures on migration and trade" are equal to the sum of lobbying expenditures on migration and trade of organizations spending money on immigration in all industries by year. 
Figure 5. Correlation between Lobbying for Migration and Trade at the Lobbying Organization Level

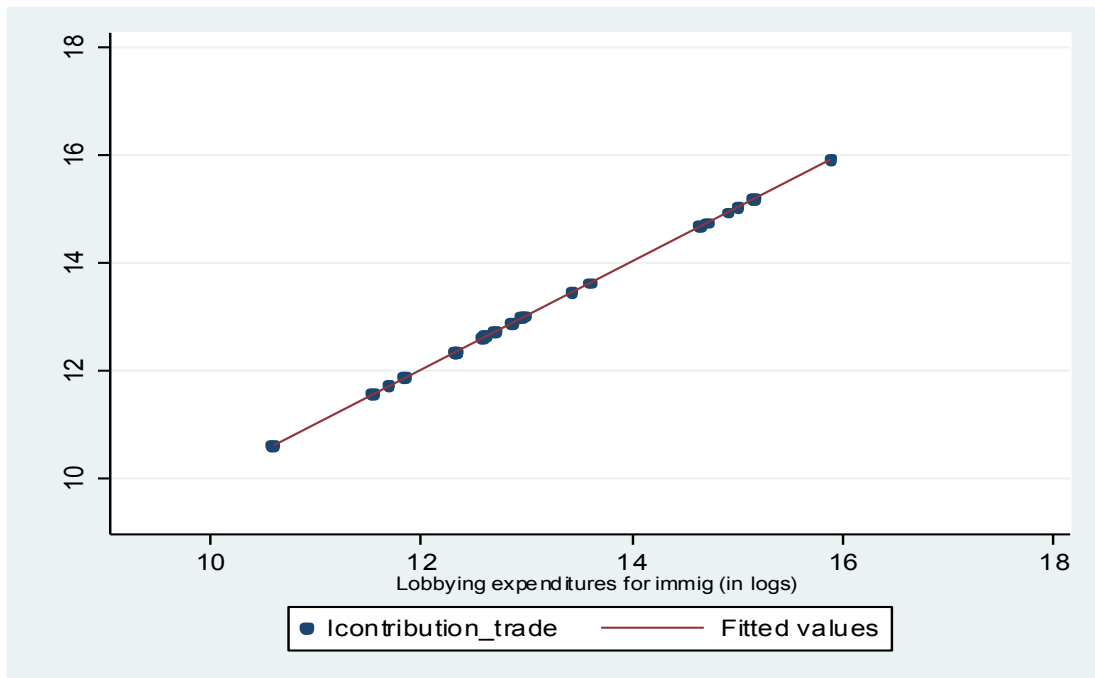

Table 2. Total i.e., on any issue lobbying expenditures of organizations spending money on immigration and trade, by year

Immigration

Trade

\begin{tabular}{|l|cccccrr|r|}
\hline \hline year & Mean & N & Sum & $\begin{array}{l}\text { Standard } \\
\text { deviation }\end{array}$ & Mean & N & Sum & $\begin{array}{l}\text { Standard } \\
\text { deviation }\end{array}$ \\
\hline $\mathbf{1 9 9 8}$ & 893,178 & 220 & $196,000,000$ & $1,876,152$ & 878,372 & 642 & $564,000,000$ & $2,031,008$ \\
$\mathbf{1 9 9 9}$ & 736,333 & 159 & $117,000,000$ & $1,294,313$ & 735,493 & 694 & $510,000,000$ & $1,428,041$ \\
$\mathbf{2 0 0 0}$ & 880,145 & 231 & $203,000,000$ & $2,054,638$ & 707,860 & 935 & $662,000,000$ & $1,552,776$ \\
$\mathbf{2 0 0 1}$ & 641,461 & 179 & $115,000,000$ & $1,267,866$ & 763,889 & 752 & $574,000,000$ & $1,604,979$ \\
$\mathbf{2 0 0 2}$ & 651,462 & 212 & $138,000,000$ & $1,421,388$ & 761,280 & 976 & $743,000,000$ & $1,666,063$ \\
$\mathbf{2 0 0 3}$ & 683,794 & 174 & $119,000,000$ & $1,375,422$ & 865,700 & 671 & $581,000,000$ & $1,819,264$ \\
$\mathbf{2 0 0 4}$ & 894,266 & 220 & $197,000,000$ & $1,888,383$ & 885,300 & 675 & $598,000,000$ & $1,872,284$ \\
$\mathbf{2 0 0 5}$ & 850,357 & 267 & $227,000,000$ & $1,738,925$ & 933,013 & 798 & $745,000,000$ & $2,098,886$ \\
\hline Total & 789,762 & 1662 & $1,310,000,000$ & $1,673,093$ & 810,135 & 6143 & $4,980,000,000$ & $1,762,520$ \\
\hline
\end{tabular}


Table 3. Lobbying expenditures on migration and trade of organizations spending money on immigration and trade, by year

Immigration

Trade

\begin{tabular}{|l|rrrrrrr|r|}
\hline \hline year & mean & $\mathbf{N}$ & sum & $\begin{array}{l}\text { Standard } \\
\text { deviation }\end{array}$ & mean & N & $\begin{array}{c}\text { Standard } \\
\text { deviation }\end{array}$ \\
\hline $\mathbf{1 9 9 8}$ & 82,432 & 220 & $18,100,000$ & 109,517 & 94,040 & 642 & $60,400,000$ & 156,036 \\
$\mathbf{1 9 9 9}$ & 83,089 & 159 & $13,200,000$ & 121,003 & 99,120 & 694 & $68,800,000$ & 150,365 \\
$\mathbf{2 0 0 0}$ & 82,616 & 231 & $19,100,000$ & 144,621 & 79,304 & 935 & $74,100,000$ & 130,065 \\
$\mathbf{2 0 0 1}$ & 71,659 & 179 & $12,800,000$ & 114,784 & 102,587 & 752 & $77,100,000$ & 161,651 \\
$\mathbf{2 0 0 2}$ & 52,266 & 212 & $11,100,000$ & 69,299 & 77,347 & 976 & $75,500,000$ & 124,888 \\
$\mathbf{2 0 0 3}$ & 76,852 & 174 & $13,400,000$ & 112,179 & 114,595 & 671 & $76,900,000$ & 190,322 \\
$\mathbf{2 0 0 4}$ & 87,179 & 220 & $19,200,000$ & 121,108 & 107,521 & 675 & $72,600,000$ & 177,309 \\
$\mathbf{2 0 0 5}$ & 86,240 & 267 & $23,000,000$ & 173,099 & 115,749 & 798 & $92,400,000$ & 256,102 \\
\hline Total & 78,168 & 1662 & $130,000,000$ & 126,706 & 97,312 & 6143 & $598,000,000$ & 171,620 \\
\hline
\end{tabular}

Table 4. Lobbying expenditures on migration and trade of organizations money ONLY on immigration and trade, by year

\begin{tabular}{|c|c|c|c|c|c|c|c|c|}
\hline & \multicolumn{4}{|c|}{ Immigration } & \multicolumn{4}{|c|}{ Trade } \\
\hline year & mean & $\mathbf{N}$ & sum & $\begin{array}{l}\text { Standard } \\
\text { deviation }\end{array}$ & mean & $\mathbf{N}$ & sum & $\begin{array}{l}\text { Standard } \\
\text { deviation }\end{array}$ \\
\hline 1998 & 122,333 & 12 & $1,468,000$ & 120,950 & 105,701 & 63 & $6,659,190$ & 148,258 \\
\hline 1999 & 125,375 & 12 & $1,504,500$ & 128,109 & 137,834 & 88 & $12,100,000$ & 208,591 \\
\hline 2000 & 176,983 & 10 & $1,769,830$ & 225,844 & 107,746 & 85 & $9,158,380$ & 170,347 \\
\hline 2001 & 124,476 & 10 & $1,244,761$ & 81,363 & 161,000 & 85 & $13,700,000$ & 216,186 \\
\hline 2002 & 126,000 & 10 & $1,260,000$ & 82,084 & 155,361 & 72 & $11,200,000$ & 177,954 \\
\hline 2003 & 104,333 & 12 & $1,252,000$ & 64,215 & 153,417 & 72 & $11,000,000$ & 192,329 \\
\hline 2004 & 110,598 & 14 & $1,548,370$ & 73,986 & 129,509 & 59 & $7,641,000$ & 171,498 \\
\hline 2005 & 93,520 & 18 & $1,683,355$ & 77,483 & 107,309 & 97 & $10,400,000$ & 144,180 \\
\hline Total & 119,702 & 98 & $11,700,000$ & 110,740 & 131,906 & 621 & $81,900,000$ & 181,337 \\
\hline
\end{tabular}


Table 5. Total (i.e., on any issue) lobbying expenditures of organizations spending money on immigration and trade, by industry, top 50, CRP classification, in 1998-2005

\begin{tabular}{|c|c|c|c|c|c|c|c|}
\hline \multicolumn{4}{|c|}{ Immigration } & \multicolumn{4}{|c|}{ Trade } \\
\hline Industry (CRP classification) & Mean & $\overline{\mathbf{N}}$ & Sum & Industry (CRP classification) & Mean & 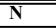 & Sum \\
\hline |Computers/Internet & $1,503,544$ & 123 & $185,000,000$ & Computers/Internet & $1,003,548$ & 325 & $326,000,000$ \\
\hline Automotive & $3,059,453$ & 28 & $85,700,000$ & Insurance & $1,694,670$ & 162 & $275,000,000$ \\
\hline Misc Manufacturing \& Distributin & $2,056,955$ & 39 & $80,200,000$ & Automotive & $1,407,872$ & 164 & $231,000,000$ \\
\hline Agricultural Services \& Products & $2,180,490$ & 28 & $61,100,000$ & Defense Aerospace & $2,433,202$ & 85 & $207,000,000$ \\
\hline Telephone Utilities & $6,611,470$ & 9 & $59,500,000$ & Business Associations & $1,100,278$ & 184 & $202,000,000$ \\
\hline Business Associations & $3,879,333$ & 15 & $58,200,000$ & Air Transport & $1,424,875$ & 127 & $181,000,000$ \\
\hline Education & 190,244 & 296 & $56,300,000$ & Chemical \& Related Manufacturing & 582,402 & 261 & $152,000,000$ \\
\hline Pharmaceuticals / Health Product & $1,896,738$ & 28 & $53,100,000$ & Agricultural Services \& Products & 635,948 & 211 & $134,000,000$ \\
\hline Oil \& Gas & $1,908,955$ & 27 & $51,500,000$ & Commercial Banks & $2,660,327$ & 45 & $120,000,000$ \\
\hline Telecom Services \& Equipment & $2,833,410$ & 16 & $45,300,000$ & Forestry \& Forest Products & 673,280 & 124 & $83,500,000$ \\
\hline Air Transport & $1,158,382$ & 35 & $40,500,000$ & Electronics Mfg \& Services & 516,330 & 141 & $72,800,000$ \\
\hline Business Services & $1,273,613$ & 31 & $39,500,000$ & Food Processing \& Sales & 365,513 & 194 & $70,900,000$ \\
\hline Defense Aerospace & $2,234,696$ & 14 & $31,300,000$ & Beer, Wine \& Liquor & 593,631 & 114 & $67,700,000$ \\
\hline Hospitals \& Nursing Homes & 533,982 & 55 & $29,400,000$ & Electric Utilities & 568,532 & 119 & $67,700,000$ \\
\hline Misc Unions & 614,175 & 42 & $25,800,000$ & Defense Electronics & 655,549 & 64 & $42,000,000$ \\
\hline Electronics Mfg \& Services & 560,446 & 44 & $24,700,000$ & Crop Production \& Basic Processi & 140,027 & 297 & $41,600,000$ \\
\hline Industrial Unions & $1,065,288$ & 22 & $23,400,000$ & Industrial Unions & 624,747 & 61 & $38,100,000$ \\
\hline Human Rights & 237,941 & 92 & $21,900,000$ & Food \& Beverage & 421,876 & 85 & $35,900,000$ \\
\hline Misc Issues & 329,859 & 65 & $21,400,000$ & Business Services & 916,595 & 37 & $33,900,000$ \\
\hline Republican/Conservative & $1,188,388$ & 18 & $21,400,000$ & Accountants & $1,122,641$ & 28 & $31,400,000$ \\
\hline Civil Servants/Public Officials & 217,090 & 74 & $16,100,000$ & Finance / Credit Companies & 671,986 & 42 & $28,200,000$ \\
\hline Food \& Beverage & 580,574 & 27 & $15,700,000$ & Hospitals \& Nursing Homes & $1,518,127$ & 15 & $22,800,000$ \\
\hline Public Sector Unions & $1,305,572$ & 12 & $15,700,000$ & Mining & 228,280 & 93 & $21,200,000$ \\
\hline Recreation / Live Entertainment & 400,652 & 35 & $14,000,000$ & Lawyers / Law Firms & 367,815 & 56 & $20,600,000$ \\
\hline Accountants & $1,487,111$ & 9 & $13,400,000$ & Civil Servants/Public Officials & 192,579 & 103 & $19,800,000$ \\
\hline Health Professionals & 504,724 & 26 & $13,100,000$ & Building Materials \& Equipment & 268,860 & 70 & $18,800,000$ \\
\hline Securities \& Investment & 840,653 & 14 & $11,800,000$ & Dairy & 223,632 & 63 & $14,100,000$ \\
\hline Transportation Unions & 704,750 & 16 & $11,300,000$ & Home Builders & 475,447 & 22 & $10,500,000$ \\
\hline Tobacco & $11,200,000$ & 1 & $11,200,000$ & Misc Energy & 188,240 & 54 & $10,200,000$ \\
\hline Lawyers / Law Firms & 451,698 & 24 & $10,800,000$ & Construction Services & 265,730 & 35 & $9,300,553$ \\
\hline TV / Movies / Music & 814,715 & 13 & $10,600,000$ & General Contractors & 302,003 & 30 & $9,060,093$ \\
\hline Commercial Banks & $2,710,000$ & 3 & $8,130,000$ & Education & 160,042 & 56 & $8,962,375$ \\
\hline Food Processing \& Sales & 289,719 & 28 & $8,112,117$ & Health Services/HMOs & 650,898 & 13 & $8,461,674$ \\
\hline Real Estate & $1,594,000$ & 5 & $7,970,000$ & Livestock & 268,034 & 31 & $8,309,065$ \\
\hline Finance / Credit Companies & $1,954,750$ & 4 & $7,819,000$ & Casinos / Gambling & 343,571 & 21 & $7,215,000$ \\
\hline Lodging / Tourism & 334,565 & 23 & $7,695,000$ & Building Trade Unions & 222,126 & 29 & $6,441,667$ \\
\hline Forestry \& Forest Products & $1,097,865$ & 7 & $7,685,058$ & Human Rights & 234,164 & 27 & $6,322,422$ \\
\hline Beer, Wine \& Liquor & 824,192 & 9 & $7,417,729$ & Lodging / Tourism & 541,364 & 11 & $5,955,000$ \\
\hline Defense Electronics & 911,063 & 8 & $7,288,500$ & Environment & 200,679 & 28 & $5,618,997$ \\
\hline Sea Transport & 901,833 & 8 & $7,214,663$ & Misc Business & 161,526 & 29 & $4,684,264$ \\
\hline Insurance & $2,193,333$ & 3 & $6,580,000$ & Foreign \& Defense Policy & 135,667 & 25 & $3,391,674$ \\
\hline Non-profits, Foundations \& Phila & 218,667 & 30 & $6,560,000$ & Misc Communications/Electronics & 227,692 & 13 & $2,960,000$ \\
\hline Crop Production \& Basic Processi & 286,767 & 20 & $5,735,332$ & Health Professionals & 212,964 & 11 & $2,342,600$ \\
\hline Chemical \& Related Manufacturing & 423,868 & 12 & $5,086,420$ & Lobbyists & 133,200 & 15 & $1,998,000$ \\
\hline Building Materials \& Equipment & 702,763 & 7 & $4,919,342$ & Environmental Svcs/Equipment & 102,000 & 10 & $1,020,000$ \\
\hline Other-Other & 314,092 & 15 & $4,711,383$ & Fisheries \& Wildlife & 91,667 & 6 & 550,000 \\
\hline Dairy & 337,154 & 13 & $4,383,000$ & Democratic/Liberal & 189,782 & 2 & 379,564 \\
\hline Casinos / Gambling & 528,750 & 8 & $4,230,000$ & Clergy \& Religious Organizations & 107,573 & 2 & 215,145 \\
\hline Retail Sales & 574,286 & 7 & $4,020,000$ & Gun Control & 80,000 & 2 & 160,000 \\
\hline Health Services/HMOs & 312,604 & 12 & $3,751,250$ & Gun Rights & 120,000 & 1 & 120,000 \\
\hline
\end{tabular}


Table 6. Lobbying expenditures on migration and trade of organizations spending money on these issues, by industry, CRP classification, in 1998-2005

\begin{tabular}{|c|c|c|c|c|c|c|c|}
\hline \multicolumn{4}{|c|}{ Immigration } & \multicolumn{4}{|c|}{ Trade } \\
\hline Industry (CRP classification) & mean & $\overline{\mathbf{N}}$ & sum & IIndustry (CRP classification) & mean & 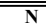 & sum \\
\hline \begin{tabular}{|l|} 
Computers/Internet \\
\end{tabular} & 136,511 & 123 & $16,800,000$ & Computers/Internet & 118,326 & 325 & $38,500,000$ \\
\hline Misc Issues & 135,655 & 65 & $8,817,561$ & Business Associations & 204,296 & 184 & $37,600,000$ \\
\hline Education & 23,449 & 296 & $6,940,910$ & Insurance & 195,374 & 162 & $31,700,000$ \\
\hline Air Transport & 160,333 & 35 & $5,611,670$ & Automotive & 123,363 & 164 & $20,200,000$ \\
\hline Hospitals \& Nursing Homes & 93,761 & 55 & $5,156,856$ & Air Transport & 153,032 & 127 & $19,400,000$ \\
\hline Misc Manufacturing \& Distributin & 130,663 & 39 & $5,095,843$ & Forestry \& Forest Products & 156,055 & 124 & $19,400,000$ \\
\hline Automotive & 170,844 & 28 & $4,783,620$ & Chemical \& Related Manufacturing & 70,007 & 261 & $18,300,000$ \\
\hline Pharmaceuticals / Health Product & 154,597 & 28 & $4,328,723$ & Crop Production \& Basic Processi & 50,649 & 297 & $15,000,000$ \\
\hline Telephone Utilities & 477,450 & 9 & $4,297,054$ & Defense Aerospace & 174,845 & 85 & $14,900,000$ \\
\hline Human Rights & 46,574 & 92 & $4,284,772$ & Beer, Wine \& Liquor & 116,766 & 114 & $13,300,000$ \\
\hline Business Associations & 266,488 & 15 & $3,997,322$ & Agricultural Services \& Products & 58,772 & 211 & $12,400,000$ \\
\hline Business Services & 119,143 & 31 & $3,693,440$ & Food Processing \& Sales & 63,449 & 194 & $12,300,000$ \\
\hline Telecom Services \& Equipment & 227,018 & 16 & $3,632,281$ & Electronics Mfg \& Services & 82,099 & 141 & $11,600,000$ \\
\hline Oil \& Gas & 132,035 & 27 & $3,564,937$ & Commercial Banks & 212,084 & 45 & $9,543,785$ \\
\hline Agricultural Services \& Products & 117,524 & 28 & $3,290,668$ & Electric Utilities & 66,679 & 119 & $7,934,787$ \\
\hline Electronics Mfg \& Services & 56,069 & 44 & $2,467,027$ & Food \& Beverage & 77,077 & 85 & $6,551,511$ \\
\hline Health Professionals & 88,351 & 26 & $2,297,130$ & Mining & 60,913 & 93 & $5,664,865$ \\
\hline Recreation / Live Entertainment & 55,684 & 35 & $1,948,928$ & Accountants & 147,665 & 28 & $4,134,612$ \\
\hline Civil Servants/Public Officials & 25,811 & 74 & $1,910,011$ & Building Materials \& Equipment & 56,017 & 70 & $3,921,162$ \\
\hline Misc Agriculture & 146,390 & 13 & $1,903,071$ & Industrial Unions & 55,549 & 61 & $3,388,463$ \\
\hline Accountants & 202,036 & 9 & $1,818,323$ & Lawyers / Law Firms & 57,713 & 56 & $3,231,953$ \\
\hline Defense Aerospace & 115,031 & 14 & $1,610,429$ & Misc Business & 109,081 & 29 & $3,163,359$ \\
\hline Food \& Beverage & 58,898 & 27 & $1,590,238$ & Dairy & 48,622 & 63 & $3,063,186$ \\
\hline Lodging / Tourism & 68,771 & 23 & $1,581,738$ & Business Services & 74,604 & 37 & $2,760,356$ \\
\hline Foreign \& Defense Policy & 57,051 & 27 & $1,540,387$ & Defense Electronics & 41,394 & 64 & $2,649,237$ \\
\hline Industrial Unions & 68,433 & 22 & $1,505,519$ & Finance / Credit Companies & 51,970 & 42 & $2,182,731$ \\
\hline Lawyers / Law Firms & 61,535 & 24 & $1,476,848$ & General Contractors & 71,716 & 30 & $2,151,465$ \\
\hline Misc Unions & 34,949 & 42 & $1,467,840$ & Foreign \& Defense Policy & 68,420 & 25 & $1,710,488$ \\
\hline Republican/Conservative & 80,404 & 18 & $1,447,275$ & Civil Servants/Public Officials & 15,509 & 103 & $1,597,455$ \\
\hline Other-Other & 92,101 & 15 & $1,381,522$ & Construction Services & 44,967 & 35 & $1,573,860$ \\
\hline Food Processing \& Sales & 45,527 & 28 & $1,274,768$ & Hospitals \& Nursing Homes & 101,890 & 15 & $1,528,356$ \\
\hline Securities \& Investment & 82,844 & 14 & $1,159,817$ & Misc Energy & 27,485 & 54 & $1,484,180$ \\
\hline Sea Transport & 137,926 & 8 & $1,103,407$ & Casinos / Gambling & 63,006 & 21 & $1,323,128$ \\
\hline Non-profits, Foundations \& Phila & 36,201 & 30 & $1,086,036$ & Livestock & 39,577 & 31 & $1,226,884$ \\
\hline Public Sector Unions & 73,265 & 12 & 879,185 & Misc Communications/Electronics & 76,821 & 13 & 998,667 \\
\hline Building Materials \& Equipment & 114,839 & 7 & 803,870 & Health Services/HMOs & 68,245 & 13 & 887,181 \\
\hline TV / Movies / Music & 61,529 & 13 & 799,876 & Lodging / Tourism & 79,920 & 11 & 879,124 \\
\hline Finance / Credit Companies & 189,953 & 4 & 759,811 & Education & 15,692 & 56 & 878,751 \\
\hline Dairy & 51,375 & 13 & 667,869 & Home Builders & 38,307 & 22 & 842,757 \\
\hline Forestry \& Forest Products & 91,482 & 7 & 640,377 & Environment & 29,751 & 28 & 833,023 \\
\hline Misc Business & 106,315 & 6 & 637,891 & Human Rights & 19,412 & 27 & 524,114 \\
\hline Health Services/HMOs & 52,987 & 12 & 635,841 & Building Trade Unions & 14,574 & 29 & 422,653 \\
\hline Crop Production \& Basic Processi & 31,696 & 20 & 633,918 & Lobbyists & 27,397 & 15 & 410,952 \\
\hline Transportation Unions & 36,871 & 16 & 589,932 & Health Professionals & 25,678 & 11 & 282,460 \\
\hline Chemical \& Related Manufacturing & 47,622 & 12 & 571,459 & Fisheries \& Wildlife & 32,917 & 6 & 197,500 \\
\hline Retail Sales & 79,548 & 7 & 556,833 & Environmental Svcs/Equipment & 11,881 & 10 & 118,808 \\
\hline Beer, Wine \& Liquor & 61,299 & 9 & 551,695 & Clergy \& Religious Organizations & 20,725 & 2 & 41,449 \\
\hline Defense Electronics & 62,699 & 8 & 501,596 & Democratic/Liberal & 14,599 & 2 & 29,197 \\
\hline Commercial Banks & 166,791 & 3 & 500,373 & Gun Control & 13,333 & 2 & 26,667 \\
\hline Tobacco & 486,957 & 1 & 486,957 & Gun Rights & 20,000 & 1 & 20,000 \\
\hline
\end{tabular}


Table 7a. Lobbying expenditures on migration for organizations spending money ONLY on immigration, by industry, CRP classification, in 1998-2005

\begin{tabular}{|l|rrr|}
\hline Industry (CRP classification) & mean & N & sum \\
\hline Misc Issues & 216,182 & 21 & $4,539,830$ \\
Human Rights & 161,818 & 11 & $1,780,000$ \\
Foreign \& Defense Policy & 132,091 & 8 & $1,056,725$ \\
Lawyers / Law Firms & 73,269 & 14 & $1,025,761$ \\
Misc Agriculture & 178,000 & 4 & 712,000 \\
Business Services & 79,714 & 7 & 558,000 \\
Health Professionals & 114,500 & 4 & 458,000 \\
Other-Other & 57,500 & 4 & 230,000 \\
Miscellaneous Services & 212,500 & 1 & 212,500 \\
Food Processing \& Sales & 100,000 & 2 & 200,000 \\
Education & 36,000 & 5 & 180,000 \\
Civil Servants/Public Officials & 80,000 & 2 & 160,000 \\
Hospitals \& Nursing Homes & 52,667 & 3 & 158,000 \\
Misc Unions & 40,000 & 3 & 120,000 \\
Securities \& Investment & 33,333 & 3 & 100,000 \\
Pharmaceuticals / Health Product & 80,000 & 1 & 80,000 \\
Food \& Beverage & 40,000 & 1 & 40,000 \\
Pro-Israel & 40,000 & 1 & 40,000 \\
Recreation / Live Entertainment & 20,000 & 2 & 40,000 \\
Savings \& Loans & 40,000 & 1 & 40,000 \\
\hline Total & 119,702 & 98 & $11,700,000$ \\
\hline
\end{tabular}

Table $7 \mathrm{~b}$. Lobbying expenditures on trade for organizations spending money ONLY on trade, by industry, CRP classification, in 1998-2005

\begin{tabular}{|l|rrr|}
\hline \hline Industry (CRP classification) & mean & N & sum \\
\hline Business Associations & 155,035 & 82 & $12,700,000$ \\
Misc Manufacturing \& Distributin & 123,713 & 87 & $10,800,000$ \\
Forestry \& Forest Products & 360,757 & 28 & $10,100,000$ \\
Steel Production & 158,966 & 58 & $9,220,000$ \\
Crop Production \& Basic Processi & 84,371 & 62 & $5,231,000$ \\
Mining & 174,778 & 18 & $3,146,000$ \\
Retail Sales & 92,102 & 30 & $2,763,055$ \\
Misc Business & 161,188 & 17 & $2,740,194$ \\
Food Processing \& Sales & 151,656 & 18 & $2,729,805$ \\
Chemical \& Related Manufacturing & 87,185 & 27 & $2,354,000$ \\
Electronics Mfg \& Services & 115,000 & 20 & $2,300,000$ \\
Computers/Internet & 168,750 & 12 & $2,025,000$ \\
General Contractors & 700,000 & 2 & $1,400,000$ \\
Agricultural Services \& Products & 77,647 & 17 & $1,320,000$ \\
Building Materials \& Equipment & 98,846 & 13 & $1,285,000$ \\
Oil \& Gas & 177,143 & 7 & $1,240,000$ \\
Pharmaceuticals / Health Product & 67,742 & 17 & $1,151,612$ \\
Foreign \& Defense Policy & 140,000 & 8 & $1,120,000$ \\
Lawyers / Law Firms & 109,564 & 10 & $1,095,638$ \\
Food \& Beverage & 76,429 & 14 & $1,070,000$ \\
Real Estate & 306,667 & 3 & 920,000 \\
Beer, Wine \& Liquor & 77,500 & 8 & 620,000 \\
Automotive & 76,875 & 8 & 615,000 \\
Textiles & 54,545 & 11 & 600,000 \\
Printing \& Publishing & 89,167 & 6 & 535,000 \\
Tobacco & 225,000 & 2 & 450,000 \\
Electric Utilities & 120,000 & 3 & 360,000 \\
Recreation / Live Entertainment & 90,000 & 4 & 360,000 \\
Telephone Utilities & 150,000 & 2 & 300,000 \\
Misc Issues & 50,300 & 5 & 251,500 \\
Business Services & 110,000 & 2 & 220,000 \\
Misc Transport & 73,333 & 3 & 220,000 \\
TV / Movies / Music & 70,000 & 2 & 140,000 \\
Air Transport & 40,000 & 3 & 120,000 \\
Telecom Services \& Equipment & 40,000 & 3 & 120,000 \\
Fisheries \& Wildlife & 100,000 & 1 & 100,000 \\
Lobbyists & 50,000 & 1 & 50,000 \\
Securities \& Investment & 22,000 & 2 & 44,000 \\
Misc Energy & 40,000 & 1 & 40,000 \\
Dairy & 20,000 & 1 & 20,000 \\
Poultry \& Eggs & 20,000 & 1 & 20,000 \\
Republican/Conservative & 20,000 & 1 & 20,000 \\
Sea Transport & 20,000 & 1 & 20,000 \\
\hline Total & 131,906 & 621 & $81,900,000$ \\
\hline \hline
\end{tabular}


Table 8. Top 50 organizations in terms of lobbying expenditures on migration and trade, in 1998-2005

\begin{tabular}{|c|c|c|c|c|c|}
\hline Firm & $\begin{array}{c}\text { Total lobbying } \\
\text { exp }\end{array}$ & $\begin{array}{l}\text { Lobbying exp on } \\
\text { migration }\end{array}$ & Firm & $\begin{array}{c}\begin{array}{c}\text { Total lobbying } \\
\text { exp }\end{array} \\
\end{array}$ & $\begin{array}{l}\text { Lobbying exp on } \\
\text { trade }\end{array}$ \\
\hline Microsoft Corp & $48,220,000$ & $3,564,231$ & US Chamber of Commerce & $77,432,880$ & $10,400,000$ \\
\hline $\begin{array}{l}\text { Motorola Inc } \\
\text { Business Roundtable }\end{array}$ & $\begin{array}{r}33,293,458 \\
37,460,000\end{array}$ & $\begin{array}{l}2,660,473 \\
2,514,167\end{array}$ & $\begin{array}{l}\text { Northrop Grumman } \\
\text { Pharmaceutical Rsrch \& Mfrs of America }\end{array}$ & $\begin{array}{l}76,916,386 \\
86202000\end{array}$ & $\begin{array}{l}7,142,483 \\
6053,933\end{array}$ \\
\hline American Farm Bureau Federation & $49,589,013$ & $2,505,281$ & Sprint Corp & $47,276,585$ & $6,675,330$ \\
\hline United to Secure America & $5,110,000$ & $2,276,667$ & Business Roundtable & $88,240,000$ & $6,013,287$ \\
\hline American Hospital Assn & $13,420,000$ & $2,236,667$ & Emergency Cmte for American Trade & $5,940,000$ & $5,550,000$ \\
\hline Intel Corp & $27,210,000$ & $2,225,185$ & Boeing $\mathrm{Co}$ & $68,273,310$ & $5,408,107$ \\
\hline Federation for Amer Immigration Reform & $2,200,000$ & $2,200,000$ & Investment Co Institute & $37,777,000$ & $5,317,040$ \\
\hline Verizon Communications & $33,110,000$ & $2,197,689$ & Securities Industry Assn & $52,307,518$ & $4,615,882$ \\
\hline Texas Instruments & $17,122,728$ & $2,004,260$ & Textron Inc & $36,460,000$ & $4,576,115$ \\
\hline National Assn of Manufacturers & $40,080,585$ & $1,966,480$ & Coalition for Fair Lumber Imports & $5,946,980$ & $4,556,585$ \\
\hline $\begin{array}{l}\text { US Border Control } \\
\text { U. }\end{array}$ & $3,741,110$ & $1,850,650$ & Citigroup Ine & $51,115,000$ & $4,313,765$ \\
\hline Disney Worldwide Services & $26,738,800$ & $1,790,415$ & Merck \& Co & $41,672,294$ & $4,180,079$ \\
\hline American Council on Intl Personnel & $1,670,000$ & $1,670,000$ & BellSouth Corp & $32,583,435$ & $4,170,843$ \\
\hline American Electronics Assn & $18,804,902$ & $1,599,212$ & British Columbia Lumber Trade Council & $5,000,000$ & $4,160,000$ \\
\hline EDS Corp & $17,045,832$ & $1,579,240$ & General Electric & $122,100,000$ & $4,027,142$ \\
\hline IBM Corp & $29,852,000$ & $1,528,373$ & IBM Corp & $47,372,000$ & $3,907,789$ \\
\hline Delta Airlines & $14,280,000$ & $1,364,444$ & Distilled Spirits Council & $21,275,708$ & $3,893,704$ \\
\hline Hebrew Immigrant Aid Society & $1,255,225$ & $1,255,225$ & AT\&T & $49,963,499$ & $3,842,748$ \\
\hline Eli Lilly \& Co & $16,690,000$ & $1,195,061$ & Microsoft Corp & $54,720,000$ & $3,814,231$ \\
\hline Accenture & $11,899,000$ & $1,176,559$ & American International Group & $44,618,300$ & $3,808,708$ \\
\hline National Council of Agric Employers & $2,535,000$ & $1,146,071$ & American Council of Life Insurers & $33,613,948$ & $3,806,847$ \\
\hline International Council of Cruise Lines & $7,214,663$ & $1,103,407$ & Abbott Laboratories & $32,326,000$ & $3,653,557$ \\
\hline $\begin{array}{l}\text { Continental Airlines } \\
\text { Coses }\end{array}$ & $5,235,927$ & $1,069,416$ & National Foreign Trade Council & $10,806,000$ & $3,470,167$ \\
\hline $\begin{array}{l}\text { DaimlerChrysler } \\
\text { Das }\end{array}$ & $19,295,905$ & $1,059,511$ & 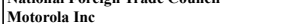 & $43,000,369$ & $3,397,518$ \\
\hline SBC Communications & $13,344,729$ & $1,053,865$ & Advanced Medical Technology Assn & $23,842,974$ & $3,357,162$ \\
\hline Shell Oil & $15,917,789$ & $1,051,698$ & Eli Lilly \& Co & $39,596,890$ & $3,341,846$ \\
\hline Commonwealth of the $\mathrm{N}$ Mariana Islands & $3,800,000$ & $1,020,533$ & Philip Morris & $75,528,000$ & $3,304,895$ \\
\hline General Motors & $23,440,000$ & $1,012,967$ & Tailored Clothing Assn & $3,600,000$ & $3,220,000$ \\
\hline Human Rights Campaign & $8,272,498$ & $1,007,668$ & Ford Motor Co & $58,510,808$ & $3,092,824$ \\
\hline Major League Baseball Commissioner's Ofc & $8,372,801$ & 912,806 & Altria Group & $39,505,000$ & $2,963,544$ \\
\hline Christian Coalition & $15,380,000$ & 911,157 & AFLAC Ine & $19,920,000$ & $2,918,095$ \\
\hline Chevron Corp & $8,550,000$ & 855,000 & New York Life Insurance & $18,960,000$ & $2,894,881$ \\
\hline United Airlines & $4,400,000$ & 797,333 & News Corp & $21,916,000$ & $2,836,372$ \\
\hline United Auto Workers & $15,655,390$ & 794,666 & SBC Communications & $45,447,736$ & $2,824,350$ \\
\hline Western Pacific Economic Council & $2,350,000$ & 783,333 & Intel Corp & $34,310,000$ & $2,816,851$ \\
\hline Agricultural Cltn for Immigration Reform & 892,000 & 757,000 & GlaxoSmithKline & $24,470,000$ & $2,810,141$ \\
\hline $\begin{array}{l}\text { Honda North America } \\
\text { How }\end{array}$ & $7,850,457$ & 738,058 & Johnson \& Johnson & $23,665,000$ & $2,789,786$ \\
\hline Sun Microsystems & $6,540,000$ & 737,950 & American Insurance Assn & $32,796,161$ & $2,749,042$ \\
\hline Oracle Corp & $7,500,590$ & 735,801 & Lockheed Martin & $60,626,287$ & $2,704,506$ \\
\hline $\begin{array}{l}\text { Oracie Corp } \\
\text { General Electric }\end{array}$ & $\begin{array}{l}1,500,990 \\
16,900,000\end{array}$ & $\begin{array}{l}73,5,801 \\
734,783\end{array}$ & $\begin{array}{l}\text { Loconeed Martin Policy Project } \\
\text { Computer Systems Pole }\end{array}$ & $\begin{array}{r}60,620,287 \\
6,840,400\end{array}$ & $2,685,720$ \\
\hline Lockheed Martin & $17,080,000$ & 718,235 & American Farm Bureau Federation & $49,589,013$ & $2,505,281$ \\
\hline Natl Assn of Public Hosp \& Health Sys & $3,520,000$ & 710,619 & $\begin{array}{l}\text { Prudential Financial } \\
\text { Pol }\end{array}$ & $20,185,745$ & $2,497,337$ \\
\hline 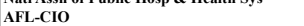 & $18,230,000$ & 694,634 & $\begin{array}{l}\text { Pernod Ricard } \\
\text { Pall }\end{array}$ & $7,428,000$ & $2,496,000$ \\
\hline Biotechnology Industry Organization & $10,659,796$ & 671,146 & DaimlerChrysler & $37,419,499$ & $2,473,099$ \\
\hline English First & $4,550,000$ & 653,143 & United Defense & $8,723,893$ & $2,463,705$ \\
\hline Abbott Laboratories & $6,717,000$ & 627,700 & Bristol-Myers Squibb & $36,920,579$ & $2,408,540$ \\
\hline Ford Motor Co & $13,080,000$ & 622,857 & Debswana Diamond Co & $2,420,000$ & $2,400,000$ \\
\hline Air Transport Assn of America & $3,107,922$ & 621,584 & General Motors & $60,706,192$ & $2,381,741$ \\
\hline Principal Financial Group & $9,554,140$ & 616,124 & Hong Kong Trade Development Council & $5,060,000$ & $2,380,000$ \\
\hline
\end{tabular}


Table 9. Lobbying expenditures on migration and trade from lobbying reports of organizations where ONLY migration/trade appears as a policy issue (top 40 for trade), in 1998-2005

\begin{tabular}{|c|c|c|c|}
\hline Firm & $\begin{array}{c}\text { Lobbying exp on } \\
\text { migration }\end{array}$ & Firm & Lobbying exp on trade \\
\hline Federation for Amer Immigration Reform & $2,200,000$ & Emergency Cmte for American Trade & $5,980,000$ \\
\hline American Council on Intl Personnel & $1,670,000$ & British Columbia Lumber Trade Council & $4,320,000$ \\
\hline US Border Control & $1,259,830$ & Coalition for Fair Lumber Imports & $3,996,190$ \\
\hline Hebrew Immigrant Aid Society & $1,255,225$ & Tailored Clothing Assn & $3,340,000$ \\
\hline Agricultural Cltn for Immigration Reform & 712,000 & Debswana Diamond Co & $2,380,000$ \\
\hline Fragomen Del Rey et al & 565,000 & European-American Business Council & $2,195,000$ \\
\hline O'Grady Peyton International & 556,000 & British Columbia Softwood Trade Council & $1,975,000$ \\
\hline NumbersUSA.com & 480,000 & Japan Iron \& Steel Federation & $1,880,000$ \\
\hline American Immigration Lawyers Assn & 430,761 & Dole Food & $1,820,000$ \\
\hline Southwestern/Great American Inc & 340,000 & Integrated Steel Producers Coalition & $1,820,000$ \\
\hline AIS Inc & 210,000 & Footwear Distribs \& Retailers of America & $1,413,055$ \\
\hline Coalition for Comprehensive Imm Reform & 210,000 & Japan Electronics \& Info Tech Industries & $1,270,000$ \\
\hline IBP Inc & 200,000 & Nucor Corp & $1,200,000$ \\
\hline Commission on Grads Foreign Nursing Schl & 180,000 & Canfor Corp & $1,160,000$ \\
\hline National Assn of Immigration Judges & 160,000 & Hynix Semiconductor & $1,150,000$ \\
\hline National Immigration Forum & 160,000 & Evans International & $1,120,000$ \\
\hline United to Secure America & 150,000 & Nikon Corp & $1,100,000$ \\
\hline United Farm Workers & 120,000 & ED\&F Man & $1,082,000$ \\
\hline Assomull Mukesh & 100,000 & ANSAC & $1,040,000$ \\
\hline US Cmte for Refugees \& Immigrants & 90,000 & Intellectual Property Committee & $1,040,000$ \\
\hline Eurapair International & 80,000 & Consuming Industries Trade Action Cltn & 940,000 \\
\hline Norbrook Laboratories & 80,000 & American Standard Development Co & 900,000 \\
\hline Banner Health Care & 68,000 & Renova Inc & 900,000 \\
\hline American Business for Legal Immigration & 60,000 & Willkie Farr \& Gallagher & 880,000 \\
\hline Just Care & 60,000 & European Confed of Iron \& Steel Indus & 840,000 \\
\hline Caribbean Marine Service & 40,000 & Orlando Food & 804,184 \\
\hline Council of Jewish Federations & 40,000 & Ad Hoc Nitrogen Committee & 780,000 \\
\hline Israel Discount Bank of New York & 40,000 & Koenig \& Bauer & 780,000 \\
\hline Pepper Hamilton LLP & 30,000 & Northwest Fruit Exporters & 773,000 \\
\hline St Bernard Hospital & 30,000 & JC Bamford & 720,000 \\
\hline Compete America & 20,000 & Clariant Corp & 660,000 \\
\hline Fed of Employers \& Workers of America & 20,000 & JD Irving Ltd & 640,000 \\
\hline McKinsey \& Co & 20,000 & Goss International & 600,000 \\
\hline Six Flags & 20,000 & Sabic Americas & 600,000 \\
\hline Victor Alberto Venero Garrido & 20,000 & New Zealand-US Business Council & 580,000 \\
\hline Washington Soccer Partners & 20,000 & FSCL/Gay \& Robins/RGVSG & 574,000 \\
\hline Wu David & 20,000 & American-Australian Free Trade Agmt Cltn & 570,000 \\
\hline Bangladeshi-American Friendship Society & 14,000 & Arcelor SA & 560,000 \\
\hline
\end{tabular}


Table A1. List of issues in lobbying reports

\begin{tabular}{|c|c|c|c|}
\hline Code & Issue & Code & Issue \\
\hline ACC & Accounting & MED & Medical/Disease Research/ Clinical Labs \\
\hline ADV & Advertising & MMM & Medicare/Medicaid \\
\hline AER & Aerospace & MON & Minting/Money/ Gold Standard \\
\hline AGR & Agriculture & NAT & Natural Resources \\
\hline ALC & Alcohol \& Drug Abuse & PHA & Pharmacy \\
\hline ANI & Animals & POS & Postal \\
\hline APP & Apparel/Clothing Industry/Textiles & RRR & Railroads \\
\hline ART & Arts/Entertainment & RES & Real Estate/Land Use/Conservation \\
\hline AUT & Automotive Industry & REL & Religion \\
\hline AVI & Aviation/Aircraft/ Airlines & RET & Retirement \\
\hline BAN & Banking & ROD & Roads/Highway \\
\hline BNK & Bankruptcy & SCI & Science/Technology \\
\hline BEV & Beverage Industry & SMB & Small Business \\
\hline BUD & Budget/Appropriations & SPO & Sports/Athletics \\
\hline $\mathrm{CHM}$ & Chemicals/Chemical Industry & TAX & Taxation/Internal Revenue Code \\
\hline CIV & Civil Rights/Civil Liberties & TEC & Telecommunications \\
\hline CAW & Clean Air \& Water (Quality) & TOB & Tobacco \\
\hline CDT & Commodities (Big Ticket) & TOR & Torts \\
\hline $\mathrm{COM}$ & Communications/ Broadcasting/ Radio/TV & TRD & Trade (Domestic \& Foreign) \\
\hline CPI & Computer Industry & TRA & Transportation \\
\hline CSP & Consumer Issues/Safety/ Protection & TOU & Travel/Tourism \\
\hline $\mathrm{CON}$ & Constitution & TRU & Trucking/Shipping \\
\hline CPT & Copyright/Patent/ Trademark & URB & Urban Development/ Municipalities \\
\hline DEF & Defense & UNM & Unemployment \\
\hline DOC & District of Columbia & UTI & Utilities \\
\hline DIS & Disaster Planning/Emergencies & VET & Veterans \\
\hline $\mathrm{ECN}$ & Economics/Economic Development & WAS & Waste (hazardous/ solid/ interstate/ nuclear) \\
\hline EDU & Education & WEL & Welfare \\
\hline ENG & Energy/Nuclear & & \\
\hline ENV & Environmental/Superfund & & \\
\hline FAM & Family Issues/Abortion/ Adoption & & \\
\hline FIR & Firearms/Guns/ Ammunition & & \\
\hline FIN & Financial Institutions/Investments/ Securities & & \\
\hline FOO & Food Industry (Safety, Labeling, etc.) & & \\
\hline FOR & Foreign Relations & & \\
\hline FUE & Fuel/Gas/Oil & & \\
\hline GAM & Gaming/Gambling/ Casino & & \\
\hline GOV & Government Issues & & \\
\hline HCR & Health Issues & & \\
\hline $\mathrm{HOU}$ & Housing & & \\
\hline IMM & Immigration & & \\
\hline IND & Indian/Native American Affairs & & \\
\hline INS & Insurance & & \\
\hline LBR & Labor Issues/Antitrust/ Workplace & & \\
\hline LAW & Law Enforcement/Crime/ Criminal Justice & & \\
\hline MAN & Manufacturing & & \\
\hline MAR & Marine/Maritime/ Boating/Fisheries & & \\
\hline MIA & Media (Information/ Publishing) & & \\
\hline
\end{tabular}


Table A2. Sample Lobbying Report

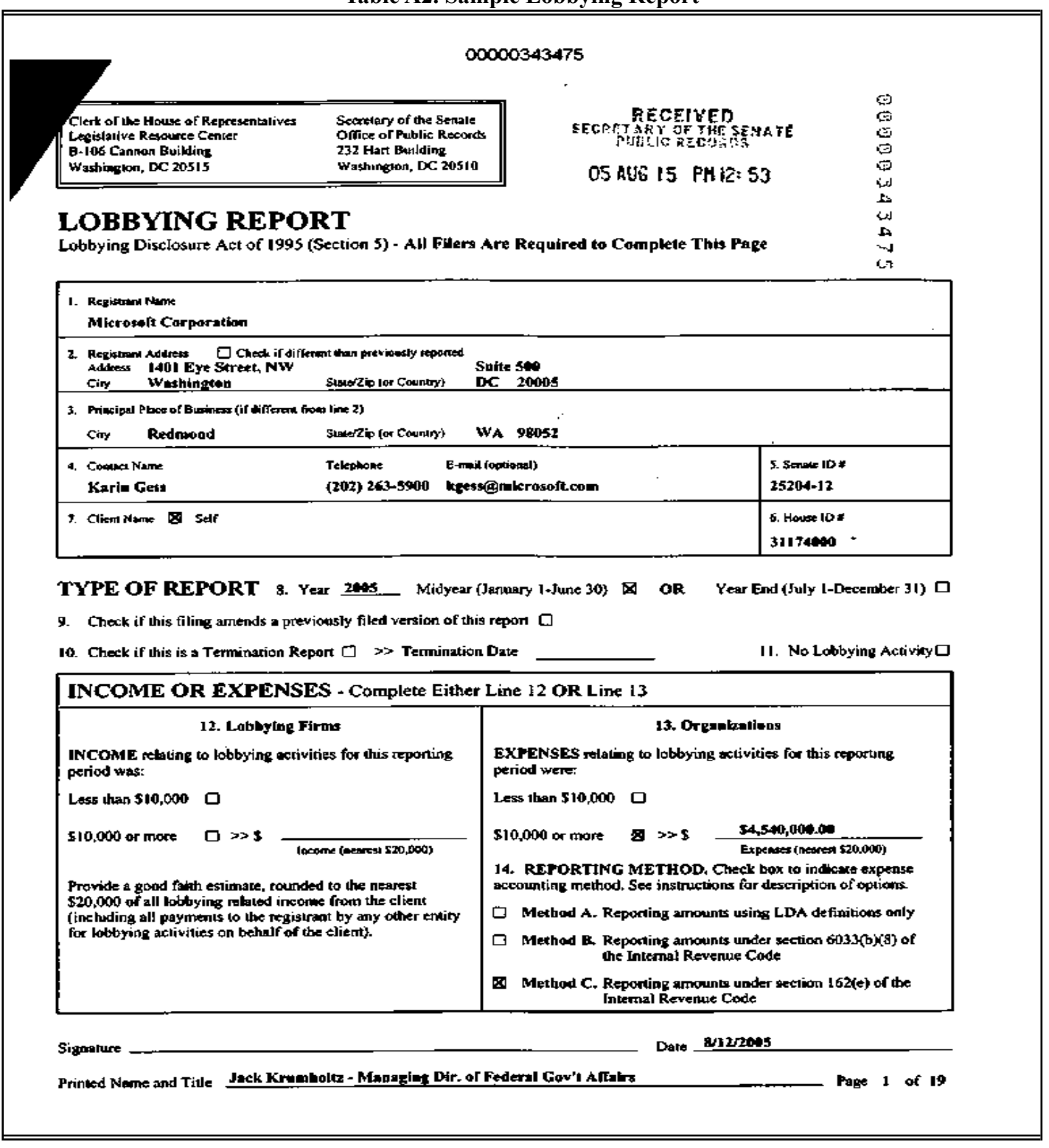


Appendix Table A2. Sample Lobbying Report (cont.)

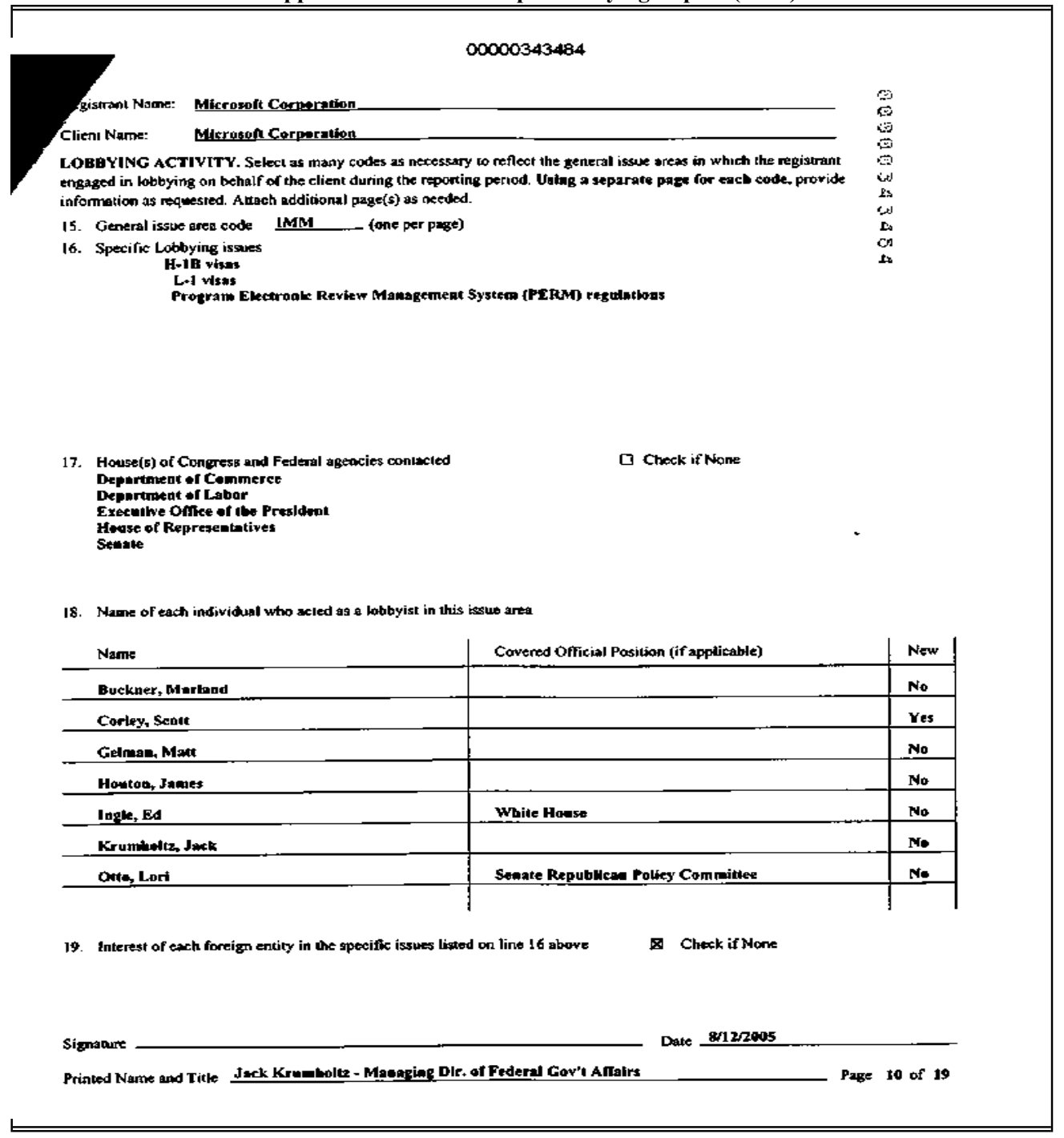


Appendix Table A2. Sample Lobbying Report (cont.)

00000343492

egistrant Name: Mitrosoff Corpormian

Client Name:

Mkrosofi Corporatien

LOsBYING ACTIVITY. Select as many codes as wecessary to reflect the gerneral issue areas in which the registram

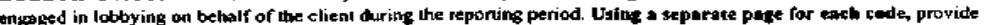
information as requested. Ampch additional pagers s) as needed.

15. General issue area cods IRB fone per page)

16. Specific Lobbying issues

Spacific Lobbying isoues Spenting 301 Spextion 301

Penami, Thadland, and Moracen

Software piracy and peocurement bssmes it Chins

(TRIPS)

Interpretation and eaforcement of the wTO Agreement en Trade-Feloted Aspects of Intellectalal Property

Agenda for further negotintions la Dohs Development Rownd of wTO tolkes

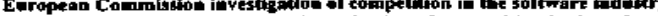

Korean Fair Trade Cormuision's inventization of competliten in the soliwnre industry

17. House(s) of Congress and Federal agencies contacted

$\square$ Chect if None

Deportament of Commerce

Departmeat of Justhee

Departinest or State

Execulive Office or the Preside

Executive Ortice or the Preste

Federal Trade Commission

18. Name of tach individual who acted as a lobbyist in this issue area

\begin{tabular}{|c|c|c|}
\hline Name & Covered Official Position (if applicable) & New \\
\hline Brodty, Betsy & & No \\
\hline Buckner, Marland & & No \\
\hline Cortey, Sowt & & Yes \\
\hline Gelinean, Mart & & No \\
\hline Howtoo, James & & No \\
\hline Ingle, Ed & White House & Ne \\
\hline Krumbelta, Jack & & No \\
\hline
\end{tabular}

19. Interest of each foreign entity in the specific issures listed on lbe 16 above

a Conek if Nano

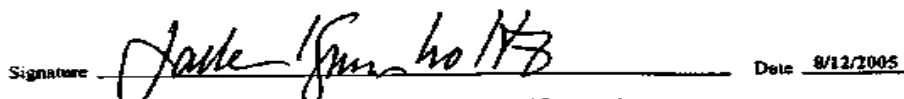

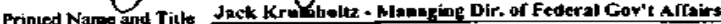

